\title{
HEATS, EQUILIBRIUM CONSTANTS, AND FREE ENERGIES OF FORMATION OF THE ACETYLENE HYDROCARBONS THROUGH THE PENTYNES, TO $1,500^{\circ} \mathrm{K}^{1}$
}

\author{
By Donald D. Wagman, John E. Kilpatrick, ${ }^{2}$ Kenneth S. Pitzer, ${ }^{3}$ and Frederick \\ D. Rossini
}

ABSTRACT

Values are presented for the following thermodynamic properties for acetylene, propyne (methylacetylene), 1-butyne (ethylacetylene), 2-butyne (dimethylacetylene), 1-pentyne (n-propylacetylene), 2-pentyne (methylethylacetylene), and 3-methyl-1-butyne (isopropylacetylene), in the gaseous state, to $1,500^{\circ} \mathrm{K}$ : The heat-content function, $\left(H^{\circ}-H^{\circ}{ }_{0}\right) / T$; the free-energy function, $\left(F^{\circ}-H^{\circ}{ }_{0}\right) / T$; the entropy, $S^{\circ}$; the heat content, $H^{\circ}-H_{0}^{\circ}$; the heat capacity, $C_{p}{ }^{\circ}$; the heat of formation from the elements, $\Delta H f^{\circ}$; the free energy of formation from the elements, $\Delta F f^{\circ}$; and the logarithm of the equilibrium constant of formation from the elements, $\log _{10} K f$.

Equilibrium constants and concentrations of components are given in tabular and graphical form for the isomerization of the two butynes and of the three pentynes as a function of temperature to $1,500^{\circ} \mathrm{K}$. Equilibrium constants are also given in tabular and graphical form for the dehydrogenation of ethane to ethylene to acetylene, of propane to propylene to propyne, of $n$-butane to 1-butene to 1 butyne, and of $n$-pentane to 1-pentene to 1-pentyne.

\section{CONTENTS}

I. Introduction

II. Units of energy and physical constants_...

III. Heat-content function, free-energy function, entropy, heat content, and heat capacity _..

1. Method and data used in the calculations

(a) Acetylene

(b) Propyne (methylacetylene) _... . . . . . . . . . . 471

(c) 1-Butyne (ethylacetylene) _........... 471

(d) 2-Butyne (dimethylacetylene) _............... 473

(e) The three pentynes.

2. Results for the seven acetylene hydrocarbons, $\mathrm{C}_{2}$ to $\mathrm{C}_{5 \ldots} \ldots \ldots-475$

IV. Heat of formation, free energy of formation, and equilibrium constant of formation

1. Method and data used in the calculations.................. 481

2. Results for the seven acetylene hydrocarbons, $\mathrm{C}_{2}$ to $\mathrm{C}_{5} \ldots$

V. Free energies and equilibrium constants of isomerization of the butynes and the pentynes

VI. Free energies and equilibrium constants of dehydrogenation, to the corresponding acetylenes, of the $\mathrm{C}_{2}$ to $\mathrm{C}_{5}$ normal paraffins and 1-alkenes

VII. References

1 This investigation was performed jointly by the American Petroleum Institute Research Project 44 on the "Collection and Analysis of Data on the Properties of Hydrocarbons" and the Thermochemical Laboratory at the National Bureau of Standards.

${ }_{2}$ Research Associate on the American Petroleum Institute Research Project 44 at the National Bureau of Standards.

3 Consultant to the American Petroleum Institute Research Project 44; Professor of Chemistry, University of California, Berkeley, Calif. 


\section{INTRODUCTION}

As part of the work of the American Petroleum Institute Research Project 44 and the Thermochemical Laboratory at the National Bureau of Standards, values have been calculated for the thermodynamic properties of the heat-content function, free-energy function, entropy, heat content, and heat capacity for the seven acetylene hydrocarbons, $\mathrm{C}_{2}$ to $\mathrm{C}_{5}$, in the gaseous state to $1,500^{\circ} \mathrm{K}$. These data have been combined with values of heats of formation at $25^{\circ} \mathrm{C}$ to calculate values of the heats, free energies, and equilibrium constants of formation of these seven acetylenes, values of the free energies and equilibrium constants of isomerization of the butynes and pentynes, and values of the free energies and equilibrium constants of dehydrogenation, to the corresponding acetylenes, of the $\mathrm{C}_{2}$ to $\mathrm{C}_{5}$ paraffin and olefin hydrocarbons, all to $1,500^{\circ} \mathrm{K}$.

\section{UNITS OF ENERGY AND PHYSICAL CONSTANTS}

The units of energy, molecular weights, and values of the fundamental constants used in this report are the same as previously described [1].

\section{HEAT-CONTENT FUNCTION, FREE-ENERGY FUNC- TION, ENTROPY, HEAT CONTENT, AND HEAT CAPACITY}

\section{METHOD AND DATA USED IN THE CALCULATIONS}

Details of the statistical calculations not described here may be found in references $[1,2,15]$.*

\section{(a) ACETYLENE}

The thermodynamic functions of acetylene were computed at each of the tabulated temperatures from the usual translational, rotational, and vibrational terms $[1,2]$ and from a number of small corrections for the deviation of the acetylene molecule from a rigid rotatorharmonic oscillator. In order to compute these corrections, it was necessary to derive an expression for the rotational-vibrational partition function for a linear molecule. For this purpose, the method of Mayer and Mayer [2] and of Stockmayer, et al [3] was extended as follows:

The energy levels of a linear molecule are given to a good approximation by the relation

$$
\begin{aligned}
\left(\epsilon-\epsilon_{0}\right) / k T=\sum_{i} v_{i} u_{i}-\sum_{i} v_{i}\left(v_{i}-1\right) Y_{i i}- \\
\sum_{i, j}^{\prime} v_{i} v_{j} Y_{i j}+j(j+1)\left[1-\beta j(j+1)-\sum_{i} v_{i} \delta_{i}\right] \sigma
\end{aligned}
$$

In the equations the following abbreviations are used:

$\epsilon=$ a given energy level of the molecule,

$\epsilon_{0}=$ the lowest energy level of the molecule,

$v_{i}, v_{j}=$ the vibrational quantum numbers of the $i, j, \ldots$ modes of vibration. The subscripts $i, j, k$ are running indices to distinguish the different modes

*Figures in brackets indicate the literature references at the end of this paper. 
of vibration, and each has as many values as the molecule has different frequencies

$j=a$ rotational quantum number and is not the same as the vibrational subscript $j$,

$\nu_{i}=$ a fundamental vibrational frequency in wave numbers,

$d_{i}=$ the degeneracy of the $i^{\text {th }}$ fundamental frequency

$u_{i}=\nu_{i} h c / k T$,

$X_{i j}=$ an anharmonicity coefficient expressed in wave numbers,

$Y_{i j}=X_{i j} h c / k T$ and is a dimensionless anharmonicity coefficient,

$\beta=\mathrm{a}$ dimensionless rotational stretching coefficient, ${ }^{4}$

$\delta_{i}=$ a dimensionless rotational-vibrational coupling coefficient,

$\sigma=B_{0} h c / k T$,

$B_{0}=h / 8 \pi^{2} I c$ and is the rotational line-spacing constant,"

$\left(\begin{array}{c}v_{i}+d_{i}-1 \\ v_{i}\end{array}\right)=$ the $v_{i}$ binominal coefficient of the $\left(v_{i}+d_{i}-1\right)$ order,

$I=$ the moment of inertia of the molecule,

$h=$ Planck's constant,

$c=$ the velocity of light,

$k=$ Boltzmann's constant,

$T=$ the absolute temperature.

The above notation follows that of Mayer and Mayer [2].

The energy-level expression is written in terms of the observed fundamentals rather than the zeroth order frequencies because (a) the fundamentals include the first-order effect of anharmonicity, and therefore this correction is reduced, (b) any future change in the anharmonicity coefficients $X_{i j}$ will alter only a small portion of the calculations, and (c) degeneracy enters the equations in a simpler manner.

The azimuthal quantum numbers were not included because they have a negligible effect on the thermodynamic properties.

In the above notation the internal partition function is then

$$
\begin{aligned}
& Q_{v j m}=\sum_{v_{1}=0}^{\infty} \ldots \sum_{v_{n}=0}^{\infty} \sum_{j=0}^{\infty}(2 j+1)\left[\Pi_{i}\left(\begin{array}{c}
v_{i}+d_{i}-1 \\
v_{i}
\end{array}\right)\right] \exp \left\{-\sum_{i} v_{i} u_{i}+\right. \\
& \left.\sum_{i} v_{i}\left(v_{i}-1\right) Y_{i i}+\sum_{i, k}^{\prime} v_{i} v_{k} Y_{i k}+j(j+1)\left[1-\beta j(j+1)-\sum_{i} v_{i} \delta_{i}\right] \sigma\right\}
\end{aligned}
$$

Summing and neglecting second-order terms,

where

$$
Q_{v \jmath_{m}}=\left[\Pi_{i}\left(1-e^{-u_{i}}\right)^{-d_{i}}\right] \sigma^{-1}\left[1+\sum_{i, j} f_{i j}+\sum_{i} \frac{d_{i} \delta_{i}}{e^{u i}-1}+\frac{2 \beta}{\sigma}+\frac{\sigma}{3}\right],
$$

$$
\begin{aligned}
& f_{i i}=d_{i}\left(d_{i}+1\right) Y_{i i}\left(\exp \left(u_{i}\right)-1\right)^{-2}, \\
& f_{i j}=d_{i} d_{j} Y_{i j}\left(\exp \left(u_{i}\right)-1\right)^{-1}\left(\exp \left(u_{j}\right)-1\right)^{-1} .
\end{aligned}
$$

${ }^{4}$ In the notation of Mayer and Mayer [2], 
The usual Einstein functions arise from the first factor. The second factor leads to the rigid rotor rotational terms. The last factor includes the first-order corrections for anharmonicity, rotationalvibrational coupling, rotational stretching, and the first EulerMaclaurin series summation correction term.

The effect of the correction terms on the thermodynamic properties was calculated by a combination of analytical and graphical methods.

The molecular constants selected for the acetylene molecule are given in table 1 . The anharmonicity coefficients were fitted, largely by least squares, to Wu's [4] assignment of the harmonics and combination bands. The anharmonicity coefficients involving frequencies $\nu_{1}, \nu_{2}$, and $\nu_{3}$ are based on many observed lines and have little uncertainty, whereas those involving $\nu_{4}$ and $\nu_{5}$ are considerably more uncertain. However, the coefficients selected reproduce satisfactorily the observed lines in the spectrum of acetylene. The remaining constants and coefficients in table 1 were taken from Mecke [5].

TABLE 1.-Molecular constants selected for the acetylene molecule

Fundamental vibration frequencies, in wave numbers, $\mathrm{cm}^{\mathbf{- 1}}$ :

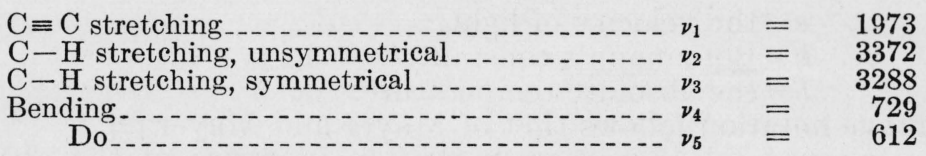

Anharmonicity coefficients, $X_{i j}$, in wave numbers, $\mathrm{cm}^{-1}$ :

\begin{tabular}{|c|c|c|c|c|c|}
\hline$j i=$ & 1 & 2 & 3 & 4 & 5 \\
\hline $\begin{array}{l}1 \\
2 \\
3 \\
4 \\
5\end{array}$ & $\begin{array}{r}12 \\
5 \\
5 \\
-2.5 \\
10\end{array}$ & $\begin{array}{r}5 \\
49 \\
73 \\
5 \\
5\end{array}$ & $\begin{array}{r}5 \\
73 \\
5 \\
5 \\
5\end{array}$ & $\begin{array}{c}-2.5 \\
5 \\
5 \\
0 \\
-2.5\end{array}$ & $\begin{array}{r}10 \\
5 \\
5 \\
-2.5 \\
-5\end{array}$ \\
\hline
\end{tabular}

Moment of inertia constants:

$$
\begin{aligned}
B_{0} & =h / 8 \pi^{2} c I=1.1764 \mathrm{~cm}^{-1}, \\
I & =23.7895 \times 10^{-40} \mathrm{~g} \mathrm{~cm}^{2} .
\end{aligned}
$$

Rotational stretching coefficient:

$$
\beta=1.556 \times 10^{-6} .
$$

Rotational-vibrational interaction coefficients:

Stretching

Bending $\delta_{1}=\delta_{2}=\delta_{3}=-0.00434$ $\delta_{4}=\delta_{5}=0.0017$. 
Table 2 gives the numerical values of the corrections (I, II, III, and IV) to the thermodynamic properties of the heat-content function, the free-energy function, and the heat capacity that are to be applied to the values calculated for the acetylene molecule on the basis of a rigid rotator-simple harmonic oscillator. Correction I arises from the actual anharmonicity of the vibrations. Correction II arises from the coupling between vibration and rotation. Correction III arises from the increase in moment of inertia with the rotational quantum number, $j$, and is referred to as the rotational stretching effect. Correction IV arises from the use of the integral in place of actual summation over the rotational energy levels and is important only in molecules having a small moment of inertia.

\section{(b) PROPYNE (METHYLACETYLENE)}

The value selected for the larger moment of inertia of methylacetylene was $98.276 \times 10^{-40} \mathrm{~g} \mathrm{~cm}^{2}$, derived from the mean of the values of $B_{0}$ reported by Herzberg, et al [6], $0.28458 \mathrm{~cm}^{-1}$, and by Badger and Bauer [7], $0.28496 \mathrm{~cm}^{-1}$. This value of the moment of inertia and the values of $1.060,1.11$, and 1.207 angstrom units for the lengths of the acetylenic $\mathrm{C}-\mathrm{H}$, the methyl $\mathrm{C}-\mathrm{H}$, and the acetylenic $\mathrm{C} \equiv \mathrm{C}$, bonds, respectively, yield 1.462 angstrom units for the length of the $\mathrm{C}-\mathrm{C}$ single bond in methylacetylene. The smaller moment of inertia then has the value $5.499 \times 10^{-40} \mathrm{~g} \mathrm{~cm}^{2}$. The symmetry number is 3 .

The entropy of translation and rotation for methylacetylene in the ideal gaseous standard state is

$$
S^{\circ}{ }_{t+r}=10.417+18.3026 \log _{10} T \text { cal/deg mole. }
$$

The vibrational frequencies selected for methylacetylene are, in wave numbers, $\mathrm{cm}^{-1}$

$\begin{array}{rr}926 & 333(2) \\ 1,380 & 642(2) \\ 2,151 & 1,041(2) \\ 2,910 & 1,444(2) \\ 3,380 & 2,995(2)\end{array}$

This assignment of frequencies is that of Crawford [9], with the exception that 3,380 is used in place of the value 3,430 recommended by Crawford for the acetylenic $\mathrm{C}-\mathrm{H}$ stretching motion. The lower value was obtained from an unpublished infrared spectrogram [16] and is supported by the value 3,300 obtained for the same vibration from the Raman spectrum of the liquid [11].

(c) 1-BUTYNE (ETHYLACETYLENE)

The following values were selected for the lengths of the bonds in the ethylacetylene molecule: Acetylenic $\mathrm{C}-\mathrm{H}, 1.060$; acetylenic $\mathrm{C} \equiv \mathrm{C}, 1.207 ; \equiv \mathrm{C}-\mathrm{C}-\frac{\prime}{-}, 1.462$; paraffinic $\mathrm{C}-\mathrm{C}, 1.54$; methylene $\mathrm{C}-\mathrm{H}, 1.11$; methyl $\mathrm{C}-\mathrm{H}, 1.09$, angstrom units. The product of the external moments of inertia is $1,164.5 \times 10^{-117}\left(\mathrm{~g} \mathrm{~cm}^{2}\right)^{3}$. The reduced internal moment of inertia is $4.847 \times 10^{-40} \mathrm{~g} \mathrm{~cm}^{2}$.

For ethylacetylene in the ideal gaseous standard state, the entropy of translation, rotation, and free internal rotation is

$$
S^{\circ}{ }_{t+r+f r}=14.407+20.5904 \log _{10} T \mathrm{cal} / \mathrm{deg} \mathrm{mole} \text {. }
$$


TABLE 2.-Values of the correction terms to the rigid-rotator-harmonic oscillator approximation for the thermodynamic functions of acetylene

[For the explanation of I, II, III, IV, see text.]

\begin{tabular}{|c|c|c|c|c|c|c|c|c|c|c|c|c|}
\hline \multirow{2}{*}{ Temperature } & \multicolumn{4}{|c|}{$\begin{array}{c}\text { Corrections to heat-content function in cal/deg. } \\
\text { mole }\end{array}$} & \multicolumn{4}{|c|}{$\begin{array}{c}\text { Corrections to free-energy function in cal/deg } \\
\text { mole }\end{array}$} & \multicolumn{4}{|c|}{ Corrections to heat capacity in cal/deg mole } \\
\hline & I & II & III & IV & I & II & III & IV & I & II & III & IV \\
\hline $\begin{array}{c}{ }^{\circ} K \\
298.16 \\
000 \\
500\end{array}$ & $\begin{array}{r}-0.0066 \\
-.0067 \\
-.0186 \\
-.0345 \\
-.0511\end{array}$ & $\begin{array}{r}+0.0000 \\
.0000 \\
.0003 \\
.0008 \\
.0014\end{array}$ & $\begin{array}{r} \\
+0.0011 \\
.0011 \\
.0015 \\
.0018 \\
.0022\end{array}$ & $\begin{array}{r}-0.0038 \\
-.0038 \\
-.0028 \\
-.0023 \\
-.0019\end{array}$ & $\begin{array}{r}+0.0012 \\
.0013 \\
.0047 \\
.0106 \\
.0184\end{array}$ & $\begin{array}{r}-0.0005 \\
-.0005 \\
-.0014 \\
-.0024 \\
-.0035\end{array}$ & $\begin{array}{r}-0.0011 \\
-.0011 \\
-.0015 \\
-.0018 \\
-.0022\end{array}$ & $\begin{array}{r}-0.0038 \\
-.0038 \\
-.0028 \\
-.0023 \\
-.0019\end{array}$ & $\begin{array}{r}-0.0347 \\
-.0352 \\
-.0760 \\
-.1177 \\
-.1519\end{array}$ & $\begin{array}{r}+0.0000 \\
.0000 \\
.0002 \\
.0006 \\
.0012\end{array}$ & $\begin{array}{r}+0.0022 \\
.0022 \\
.0029 \\
.0037 \\
.0044\end{array}$ & 0 \\
\hline $\begin{array}{r}700 \\
800 \\
900 \\
1,000 \\
1,100\end{array}$ & $\begin{array}{l}-.0676 \\
-.0831 \\
-.0972 \\
=.1099 \\
-.1213\end{array}$ & $\begin{array}{l}.0022 \\
.0030 \\
.0039 \\
.0049 \\
.0060\end{array}$ & $\begin{array}{l}.0026 \\
.0029 \\
.0033 \\
.0037 \\
.0040\end{array}$ & $\begin{array}{l}-.0016 \\
-.0014 \\
=.0012 \\
=.0011 \\
-.0010\end{array}$ & $\begin{array}{l}.0276 \\
.0377 \\
.0483 \\
.0592 \\
.0703\end{array}$ & $\begin{array}{l}-.0046 \\
-.0057 \\
-.0068 \\
-.0079 \\
-.0089\end{array}$ & $\begin{array}{l}-.0026 \\
-.0029 \\
-.0033 \\
-.0037 \\
-.0040\end{array}$ & $\begin{array}{l}-.0016 \\
=.0014 \\
=.0012 \\
=.0011 \\
-.0010\end{array}$ & $\begin{array}{l}-.1800 \\
-.2018 \\
-.2188 \\
-.2317 \\
-.2410\end{array}$ & $\begin{array}{l}.0021 \\
.0032 \\
.0045 \\
.0061 \\
.0078\end{array}$ & $\begin{array}{l}.0051 \\
.0059 \\
.0066 \\
.0073 \\
.0081\end{array}$ & 0 \\
\hline $\begin{array}{l}1,200 \\
1,300 \\
1,500\end{array}$ & $\begin{array}{l}-.1314 \\
-.1403 \\
-.1481 \\
-.1550\end{array}$ & $\begin{array}{l}.0071 \\
.0083 \\
.0094 \\
.0105\end{array}$ & $\begin{array}{l}.0044 \\
.0047 \\
.0051 \\
.0055\end{array}$ & $\begin{array}{l}-.0009 \\
-.0009 \\
=.0008 \\
-.0007\end{array}$ & $\begin{array}{l}.0813 \\
.0921 \\
.1028 \\
.1133\end{array}$ & $\begin{array}{l}-.0099 \\
-.0110 \\
-.0119 \\
-.0129\end{array}$ & $\begin{array}{l}-.0044 \\
-.0047 \\
-.0051 \\
-.0055\end{array}$ & $\begin{array}{l}-.0009 \\
-.0009 \\
-.0008 \\
-.0007\end{array}$ & $\begin{array}{l}-.2470 \\
-.2500 \\
-.2512 \\
-.2519\end{array}$ & $\begin{array}{l}.0096 \\
.0114 \\
.0133 \\
.0152\end{array}$ & $\begin{array}{l}.0088 \\
.0095 \\
.0103 \\
.0110\end{array}$ & $\begin{array}{l}0 \\
0\end{array}$ \\
\hline
\end{tabular}


No assignment of frequencies for ethylacetylene has been published. This molecule has 24 internal degrees of freedom, as follows: 9 valence stretching vibrations; 14 deformation, or bending, vibrations; and 1 hindered rotation. The selection rules permit all these frequencies to be active in both Raman and infrared spectra. The assignment of frequencies was made on the basis of the Raman spectrum [12] and the infrared spectrum [28] by means of a normal coordinate calculation and by analogy to the assignments of methylacetylene [9] and propane [13] and by comparison with the Raman spectra of other monosubstituted acetylenes [12]. The resulting assignment of frequencies follows, in wave numbers, $\mathrm{cm}^{-1}$ :

\begin{tabular}{|c|c|c|c|}
\hline \multicolumn{2}{|c|}{ Stretching modes } & \multicolumn{2}{|c|}{ Bending modes } \\
\hline $\mathrm{H}-\mathrm{C} \equiv$ & 3380 & $\mathrm{H}-\mathrm{C} \equiv \mathrm{C}$ & 642 \\
\hline $\mathrm{C} \equiv \mathrm{C}$ & 2151 & $\hat{\mathrm{H}}-\mathrm{C} \equiv \mathrm{C}\}$ & 642 \\
\hline $\mathrm{C}-\mathrm{C} \equiv$ & 840 & $\mathrm{C} \equiv \mathrm{C}-\mathrm{C}\}$ & 206 \\
\hline $\mathrm{C}-\mathrm{C}\}$ & 1068 & $\mathrm{C} \equiv \mathrm{C}-\mathrm{C}\}$ & 348 \\
\hline $\mathrm{CH}_{2}$ & 2963 & & 784 \\
\hline and & $\{2963$ & & 1005 \\
\hline $\mathrm{CH}_{3}$ & 2963 & & 1252 \\
\hline & (2963 & $\mathrm{CH}_{2}$ & 1252 \\
\hline & & and & 1314 \\
\hline & & & 1375 \\
\hline & & & \\
\hline
\end{tabular}

No experimental data on heat capacity or the entropy of the gas are available for evaluating the barrier hindering internal rotation. As the structural relations in this respect resemble those of ethane more than any other molecule, the same barrier has been used as in ethane, $2,710 \mathrm{cal} / \mathrm{mole}[17]$. The contribution of the hindered internal rotation to the respective thermodynamic properties was evaluated from the tables of Pitzer and Gwinn [15].

\section{(d) 2-BUTYNE (DIMETHYLACETYLENE)}

It has been known for some time that the values of the heat capacity and entropy of gaseous dimethylacetylene calculated statistically from the usually accepted spectroscopic and molecular data can not be made to agree well with both the heat capacity and the entropy determined experimentally. Statistical calculations involving (a) appropriate dimensions from methylacetylene, with the length of the $\mathrm{C}-\mathrm{H}$ bond in the methyl groups taken as 1.09 angstrom units, and (b) Crawford's assignment of frequencies [10], with free internal rotation, yield values of heat capacity in accord with those determined experimentally by Kistiakowsky and Rice [11], but a value of the entropy at the normal boiling point, which is $0.4 \mathrm{cal} /$ degree mole lower than the value determined calorimetrically by Osborne, Garner, and Yost [14]. Assumption of hindered rotation of the methyl groups could only lower the statistically calculated value of the entropy, which is already too low, and, furthermore, would raise the statistically calculated heat capacities above the experimentally determined values. No important change appears permissible in the lengths of the $\mathrm{C}-\mathrm{C}$ and $\mathrm{C} \equiv \mathrm{C}$ bonds, which have been determined with satisfactory accord from electron-diffraction measurements for methylacetylene and dimethylacetylene [8], and from spectroscopic measurements for 
methylacetylene $[6,7]$. The assignment of frequencies made by Crawford [9] appears to be satisfactory, as he has shown that the same potential constants reproduce the spectra of acetylene, methylacetylene, and dimethylacetylene.

In order to improve the situation slightly, two minor changes have been made in the present investigation, with regard to the molecular constants of dimethylacetylene, as follows:

(a) The length of the $\mathrm{C}-\mathrm{H}$ bond in the methyl group is taken as 1.11 angstrom units, in place of the usually accepted value of 1.09 angstrom units. Justification for this change is that the stretching frequencies associated with the $\mathrm{C}-\mathrm{H}$ bonds were calculated by Crawford [9, 10], using potential constants taken from ethane, to be lower than those actually observed. By the application of Badger's rule [29], this could mean that the lengths of the $\mathrm{C}-\mathrm{H}$ bonds in methylacetylene and dimethylacetylene are a little greater than 1.09 angstrom units. This change is even more justified because of the fact that the value of 1.11 angstrom units for the length of the $\mathrm{C}-\mathrm{H}$ bond in the methyl group leads to a value of the moment of inertia $\left(5.499 \times 10^{-40} \mathrm{~g} \mathrm{~cm}^{2}\right)$, which is in essentially exact accord with the values of the moment of inertia of the methyl group determined spectroscopically for ethane and each of the four methyl halides [30].

(b) The lowest frequency is changed from 213 to 209 wave numbers, $\mathrm{cm}^{-1}$. Justification for this change is that the lowest frequency in dimethylacetylene, which is that associated with the symmetrical bending of the carbon skeleton, has been observed only in the Raman spectrum of the liquid, and the frequency of a vibration measured in the liquid phase is often several wave numbers, $\mathrm{cm}^{-1}$, different from the frequency of the same vibration measured in the gaseous phase.

The two foregoing changes produce substantially no change in the statistically calculated values of the heat capacity but reduce the difference between the statistically calculated and experimentally determined values of the entropy from 0.4 to $0.2 \mathrm{cal} / \mathrm{deg}$ mole, which is near the uncertainty of the experimentally determined value.

On the basis of the foregoing changes, the molecular constants for dimethylacetylene are taken as follows:

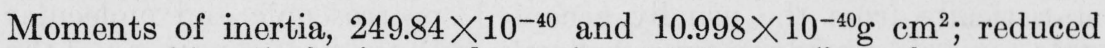
moment of inertia for internal rotation, $2.750 \times 10^{-40} \mathrm{~g} \mathrm{~cm}^{2}$; symmetry number, 18 ; frequencies,

$\begin{array}{rrrr}725 & 1126 & 209(2) & 371(2) \\ 1380 & 1380 & 1050(2) & 1029(2) \\ 2270 & 2976 & 1468(2) & 1448(2) \\ 2916 & & 2976(2) & 2966(2)\end{array}$

For dimethylacetylene in the ideal gaseous standard state, the entropy of translation and rotation, including free internal rotation, is

$$
S^{\circ}{ }_{t+r+f r}=9.758+20.5904 \log _{10} T \mathrm{cal} / \mathrm{deg} \text { mole. }
$$


(e) THE THREE PENTYNES

As neither calorimetric data nor complete spectroscopic data for any of the pentynes were available, an approximate method of calculation was used for these molecules, involving the addition to the values for 1-butyne of contributions arising from appropriate structural increments determined from the lower members of the paraffin and acetylene series. The values of the heat-content function, freeenergy function, and heat capacity were determined in this manner. From these values the entropies and heat contents were calculated.

For 1-pentyne ( $n$-propylacetylene) the values were calculated to be those for 1-butyne (ethylacetylene) plus the difference between the values for $n$-butane and propane. No correction in the free-energy function due to symmetry number is necessary.

For 2-pentyne (methylethylacetylene) the values were calculated to be those for 1-butyne plus the difference between 2-butyne (dimethylacetylene) and propyne (methylacetylene). The freeenergy function is decreased by $R \ln 2$ because of the difference in the symmetry numbers of 2-butyne and propyne.

For 3-methyl-1-butyne (isopropylacetylene), the values were calculated to be those for 1-butyne plus the difference between isobutane and propane. The free-energy function is decreased by $R \ln 3 / 2$ because of the difference in the symmetry numbers of isobutane and propane.

The required values for 2-butyne and propyne were taken from the calculations of this report, and the values for propane, $n$-butane, and isobutane were taken from Pitzer [17] and from some unpublished calculations [18].

\section{RESULTS FOR THE SEVEN ACETYLENE HYDROCARBONS, $\mathrm{C}_{2} \mathrm{TO}_{5}$}

The resulting values of the thermodynamic properties for the seven acetylene hydrocarbons through the pentynes are given in tables $3,4,5,6$, and 7 , which give, respectively, values of the heat-content function, $\left(H^{\circ}-H_{0}^{\circ}\right) / T$, the free-energy function, $\left(F^{\circ}-H_{0}^{\circ}\right) / T$, the entropy, $S^{\circ}$, the heat content, $H^{\circ}-H_{0}^{\circ}$, and the heat capacity, $C_{p}^{\circ}$.

The values given in tables $3,4,5,6$, and 7 may be compared with previously published values as follows:

(a) Values of the free-energy function for acetylene were reported by Gordon [19] and by Kassel [20]. Gordon's values for the freeenergy function at $298.16^{\circ}$ and $1,000^{\circ} \mathrm{K}$, corrected to the new values of the fundamental physical constants [1], are -39.980 and -52.127 cal/deg mole, respectively, as compared with the values -39.976 and $-52.005 \mathrm{cal} / \mathrm{deg}$ mole, respectively, as given in table 4 .

(b) Values of the heat capacity of methylacetylene and of dimethylacetylene in the gaseous state were determined experimentally by Kistiakowsky and Rice [11]. A comparison of these data with the appropriate values from table 7, obtained by Lagrangian fourpoint interpolation [21], is shown in table 8. The accord is very satisfactory. 
TABLE 3.-Values of the heat content function, $\left(H^{\circ}-H_{0}^{\circ}\right) / T$, for the seven acetylene hydrocarbons, $\mathrm{C}_{2}$ to $\mathrm{C}_{5}$, for the ideal gaseous state, to $1,500^{\circ} \mathrm{K}$

\begin{tabular}{|c|c|c|c|c|c|c|c|c|c|c|c|c|c|c|c|c|}
\hline \multirow{3}{*}{ Compound (gas) } & \multirow{3}{*}{$\begin{array}{l}\text { For- } \\
\text { mula }\end{array}$} & \multicolumn{15}{|c|}{ Temperature $^{\circ} \mathrm{K}$} \\
\hline & & 0 & 298.16 & 300 & 400 & 500 & 600 & 700 & 800 & 900 & 1,000 & 1,100 & 1,200 & 1,300 & 1,400 & 1,500 \\
\hline & & \multicolumn{15}{|c|}{ Heat-content function, $\mathrm{b}\left(H^{\circ}-H_{0}^{\circ}\right) / T$, in cal/deg mole } \\
\hline Ethyne (acetylene) & $\mathrm{C}_{2} \mathrm{H}_{2}$ & 0 & 8.021 & 8.036 & 8.853 & 9.582 & 10.212 & 10.762 & 11.249 & 11.689 & 12.090 & 12.460 & 12.802 & 13.119 & 13.416 & 13. 694 \\
\hline Propyne (methylacetylene) & $\mathrm{C}_{3} \mathrm{H}_{4}$ & 0 & 10.41 & 10.44 & 11.82 & 13.17 & 14. 44 & 15.62 & 16.72 & 17.73 & 18. 67 & 19.54 & 20.35 & 21.10 & 21.80 & 22.45 \\
\hline $\begin{array}{l}\text { 1-Butyne (ethylacetylene) } \\
\text { 2-Butyne (dimethylacetylene) }\end{array}$ & $\mathrm{C}_{4}^{\mathrm{C}_{4} \mathrm{H}_{6}}$ & $\begin{array}{l}0 \\
0\end{array}$ & $\begin{array}{l}\text { 12. } 81 \\
13.28\end{array}$ & $\begin{array}{l}12.83 \\
13.32\end{array}$ & $\begin{array}{l}15.08 \\
15.15\end{array}$ & $\begin{array}{l}17.22 \\
17.03\end{array}$ & $\begin{array}{l}19.22 \\
18.86\end{array}$ & $\begin{array}{l}21.09 \\
20.62\end{array}$ & $\begin{array}{l}22.80 \\
22.28\end{array}$ & $\begin{array}{l}24.38 \\
23.84\end{array}$ & $\begin{array}{l}25.83 \\
25.29\end{array}$ & $\begin{array}{l}27.18 \\
26.64\end{array}$ & $\begin{array}{l}28.42 \\
27.90\end{array}$ & $\begin{array}{l}29.58 \\
29.06\end{array}$ & $\begin{array}{l}30.65 \\
30.15\end{array}$ & $\begin{array}{l}31.64 \\
31.16\end{array}$ \\
\hline $\begin{array}{l}\text { 1-Pentyne } \\
\text { 2-Pentyne } \\
\text { 3-Methyl-1-butyne }\end{array}$ & $\begin{array}{l}\mathrm{C}_{5} \mathrm{H}_{8} \\
\mathrm{C}_{5} \mathrm{H}_{8} \\
\mathrm{C}_{5} \mathrm{H}_{8}\end{array}$ & $\begin{array}{l}0 \\
0 \\
0\end{array}$ & $\begin{array}{l}16.61 \\
15.68 \\
15.37\end{array}$ & $\begin{array}{l}16.64 \\
15.72 \\
15.40\end{array}$ & $\begin{array}{l}19.6 \\
18.4 \\
18.6\end{array}$ & $\begin{array}{l}22.4 \\
21.1 \\
21.6\end{array}$ & $\begin{array}{l}25.1 \\
23.6 \\
24.5\end{array}$ & $\begin{array}{l}27.5 \\
26.1 \\
27.0\end{array}$ & $\begin{array}{l}29.8 \\
28.4 \\
29.4\end{array}$ & $\begin{array}{l}31.8 \\
30.5 \\
31.5\end{array}$ & $\begin{array}{l}33.7 \\
32.4 \\
33.5\end{array}$ & $\begin{array}{l}35.5 \\
34.3 \\
35.3\end{array}$ & $\begin{array}{l}37.1 \\
36.0 \\
37.0\end{array}$ & $\begin{array}{l}38.7 \\
37.5 \\
38.5\end{array}$ & $\begin{array}{l}40.1 \\
39.0 \\
39.9\end{array}$ & $\begin{array}{l}41.4 \\
40.4 \\
41.2\end{array}$ \\
\hline
\end{tabular}

- Interpolation to other temperatures in the interval $298.16^{\circ}$ to $1,500^{\circ} \mathrm{K}$ may be made by appropriate graphical or analytical methods. For temperatures between $200^{\circ}$ and $298.15^{\circ}$ $\mathrm{K}$, values may be estimated by extrapolating the values for $300^{\circ}, 400^{\circ}, 500^{\circ}$, and $600^{\circ} \mathrm{K}$. The values in this table are given absolute accuracy of the individual values in order to retain the internal consistency of the several thermodynamic functions of a single substance, and also to retain the significance of the increments with temperature of a given thermodynamic function.

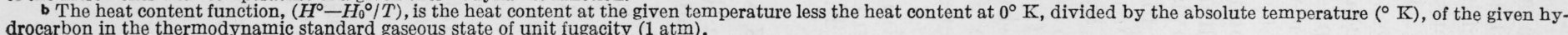


$\mathrm{T}_{\mathrm{ABLE}} 4 .-$ Values a of the free energy function, $\left(\mathrm{F}^{\circ}-\mathrm{H}_{0}^{\circ}\right) / T$, for the seven acetylene hydrocarbons, $\mathrm{C}_{2}$ to $\mathrm{C}_{5}$, for the ideal gaseous state, to $1,500^{\circ} \mathrm{K}$

\begin{tabular}{|c|c|c|c|c|c|c|c|c|c|c|c|c|c|c|c|c|}
\hline \multirow{3}{*}{ Compound (gas) } & \multirow{3}{*}{$\begin{array}{c}\text { Form- } \\
\text { ula }\end{array}$} & \multicolumn{15}{|c|}{ Temperature in ${ }^{\circ} \mathrm{K}$} \\
\hline & & 0 & 298.16 & 300 & 400 & 500 & 600 & 700 & 800 & 900 & 1,000 & 1,100 & 1,200 & 1,300 & 1,400 & 1,500 \\
\hline & & \multicolumn{15}{|c|}{ Free energy function, ${ }^{\mathrm{b}}\left(F^{\circ}-H_{0}^{\circ}\right) / T$, in cal $/$ deg mole } \\
\hline Ethyne (acetylene) & $\mathrm{C}_{2} \mathrm{H}_{2}$ & 0 & -39.976 & -40.025 & -42.451 & -44.508 & -46.313 & -47.930 & -49.400 & -50.752 & -52.005 & -53.175 & -54.275 & -55.313 & -56.296 & -57.231 \\
\hline Propyne (methylacetylene).... & $\mathrm{C}_{3} \mathrm{H}_{4}$ & 0 & -48.89 & -48.95 & -52.14 & -54.92 & -57.44 & -59.76 & -61.91 & -63.94 & -65.86 & -67.68 & -69.42 & -71.07 & -72.66 & -74.19 \\
\hline $\begin{array}{l}\text { 1-Butyne (ethylacetylene) } \\
\text { 2-Butyne (dimethylacetylene) }\end{array}$ & $\begin{array}{l}\mathrm{C}_{4} \mathrm{H}_{6} \\
\mathrm{C}_{4} \mathrm{H}_{6}\end{array}$ & $\begin{array}{l}0 \\
0\end{array}$ & $\begin{array}{l}-56.70 \\
-54.43\end{array}$ & $\begin{array}{l}-56.78 \\
-54.51\end{array}$ & $\begin{array}{l}-60.78 \\
-58.59\end{array}$ & $\begin{array}{l}-64.38 \\
-62.18\end{array}$ & $\begin{array}{l}-67.70 \\
-65.44\end{array}$ & $\begin{array}{l}-70.81 \\
-68.48\end{array}$ & $\begin{array}{l}-73.74 \\
-71.35\end{array}$ & $\begin{array}{l}-76.51 \\
-74.06\end{array}$ & $\begin{array}{l}-79.16 \\
-76.65\end{array}$ & $\begin{array}{l}-81.69 \\
-79.12\end{array}$ & $\begin{array}{l}-84.11 \\
-81.50\end{array}$ & $\begin{array}{l}-86.43 \\
-83.78\end{array}$ & $\begin{array}{l}-88.66 \\
-85.97\end{array}$ & $\begin{array}{l}-90.81 \\
-88.09\end{array}$ \\
\hline $\begin{array}{l}\text { 1-Pentyne-- } \\
\text { 2-Pentyne--1-butyne } \\
\text { 3-Methyl-1-but }\end{array}$ & $\begin{array}{l}\mathrm{C}_{5} \mathrm{H}_{8} \\
\mathrm{C}_{5} \mathrm{H}_{8} \\
\mathrm{C}_{5} \mathrm{H}_{8}\end{array}$ & $\begin{array}{l}0 \\
0 \\
0\end{array}$ & $\begin{array}{l}-62.49 \\
-63.62 \\
-60.86\end{array}$ & $\begin{array}{l}-62.60 \\
-63.72 \\
-60.95\end{array}$ & $\begin{array}{l}-67.8 \\
-68.6 \\
-65.8\end{array}$ & $\begin{array}{l}-72.5 \\
-73.0 \\
-70.3\end{array}$ & $\begin{array}{l}-76.8 \\
-77.1 \\
-74.5\end{array}$ & $\begin{array}{l}-80.9 \\
-80.9 \\
-78.5\end{array}$ & $\begin{array}{l}-84.7 \\
-84.5 \\
-82.2\end{array}$ & $\begin{array}{l}-88.3 \\
-88.0 \\
-85.8\end{array}$ & $\begin{array}{l}-91.8 \\
-91.3 \\
-89.2\end{array}$ & $\begin{array}{l}-95.1 \\
-94.5 \\
-92.5\end{array}$ & $\begin{array}{l}-98.2 \\
-97.6 \\
-95.6\end{array}$ & $\begin{array}{l}-101.2 \\
-100.5 \\
-98.7\end{array}$ & $\begin{array}{l}-104.2 \\
-103.3 \\
-101.6\end{array}$ & $\begin{array}{l}-107.0 \\
-106.1 \\
-104.4\end{array}$ \\
\hline
\end{tabular}

See footnote a f toble 3

b The free energy function, $\left(F^{\circ}-H_{0}^{\circ}\right) / T$, is the free energy at the given temperature less the heat content at $0^{\circ} \mathrm{K}$, divided by the absolute temperature $\left({ }^{\circ} \mathrm{K}\right)$, of the given hydrocarbon in the thermodynamic standard gaseous state of unit fugacity $(1 \mathrm{~atm})$. 
$\mathrm{T}_{\mathrm{ABLE}}$ 5.-Values $\mathrm{s}^{\mathrm{a}}$ of the entropy, $\mathrm{S}^{\circ}$, for the seven acetylene hydrocarbons, $\mathrm{C}_{2}$ to $\mathrm{C}_{5}$, for the ideal gaseous state, to $1,500^{\circ} \mathrm{K}$

\begin{tabular}{|c|c|c|c|c|c|c|c|c|c|c|c|c|c|c|c|c|}
\hline \multirow{3}{*}{ Compound (gas) } & \multirow{3}{*}{$\underset{\text { Fa }}{\text { Formu- }}$} & \multicolumn{15}{|c|}{ Temperature in ${ }^{\circ} \mathrm{K}$} \\
\hline & & 0 & 298.16 & 300 & 400 & 500 & 600 & 700 & 800 & 900 & 1,000 & 1,100 & 1,200 & 1,300 & 1,400 & 1,500 \\
\hline & & \multicolumn{15}{|c|}{ Entropy,b $S^{\circ}$, in cal/deg mole } \\
\hline Ethyne (acetylene) & $\mathrm{C}_{2} \mathrm{H}_{2}$ & 0 & 47.997 & 48.061 & 51.304 & 54.090 & 56.525 & 58.692 & 60.649 & 62.441 & 64.095 & 65.635 & 67.077 & 68. 432 & 69.712 & 70.925 \\
\hline Propyne (methylacetylene) & $\mathrm{C}_{3} \mathrm{H}_{4}$ & 0 & 59.30 & 59.39 & 63.96 & 68.09 & 71.88 & 75.38 & 78.63 & 81.67 & 84.53 & 87.22 & 89.77 & 92.17 & 94.46 & 96.64 \\
\hline $\begin{array}{l}\text { 1-Butyne (ethylacetylene) } \\
\text { 2-Butyne (dimethylacetylene) }\end{array}$ & $\begin{array}{l}\mathrm{C}_{4} \mathrm{H}_{6} \\
\mathrm{C}_{4} \mathrm{H}_{6}\end{array}$ & $\begin{array}{l}0 \\
0\end{array}$ & $\begin{array}{l}69.51 \\
67.71\end{array}$ & $\begin{array}{l}69.61 \\
67.83\end{array}$ & $\begin{array}{l}75.86 \\
73.74\end{array}$ & $\begin{array}{l}81.60 \\
79.21\end{array}$ & $\begin{array}{l}86.92 \\
84.30\end{array}$ & $\begin{array}{l}91.90 \\
89.10\end{array}$ & $\begin{array}{l}96.54 \\
93.63\end{array}$ & $\begin{array}{r}100.89 \\
97.90\end{array}$ & $\begin{array}{l}104.99 \\
101.94\end{array}$ & $\begin{array}{l}108.87 \\
105.76\end{array}$ & $\begin{array}{l}112.53 \\
109.40\end{array}$ & $\begin{array}{l}116.01 \\
112.84\end{array}$ & $\begin{array}{l}119.31 \\
116.12\end{array}$ & $\begin{array}{l}122.45 \\
119.25\end{array}$ \\
\hline $\begin{array}{l}\text { 1-Pentyne } \\
\text { 2-Pentyne- } \\
\text { 3-Methyl-1-butyne }\end{array}$ & $\begin{array}{l}\mathrm{C}_{5} \mathrm{H}_{8} \\
\mathrm{C}_{5} \mathrm{H}_{8} \\
\mathrm{C}_{5} \mathrm{H}_{8}\end{array}$ & $\begin{array}{l}0 \\
0 \\
0\end{array}$ & $\begin{array}{l}79.10 \\
79.30 \\
76.23\end{array}$ & $\begin{array}{l}\text { 79. } 24 \\
79.44 \\
76.35\end{array}$ & $\begin{array}{l}87.4 \\
87.0 \\
84.4\end{array}$ & $\begin{array}{l}94.9 \\
94.1 \\
91.9\end{array}$ & $\begin{array}{r}101.9 \\
100.7 \\
99.0\end{array}$ & $\begin{array}{l}108.4 \\
107.0 \\
105.5\end{array}$ & $\begin{array}{l}114.5 \\
112.9 \\
111.6\end{array}$ & $\begin{array}{l}120.1 \\
118.5 \\
117.3\end{array}$ & $\begin{array}{l}125.5 \\
123.7 \\
122.7\end{array}$ & $\begin{array}{l}130.6 \\
128.8 \\
127.8\end{array}$ & $\begin{array}{l}135.3 \\
133.6 \\
132.6\end{array}$ & $\begin{array}{l}139.9 \\
138.0 \\
137.2\end{array}$ & $\begin{array}{l}144.3 \\
142.3 \\
141.5\end{array}$ & $\begin{array}{l}148.4 \\
146.5 \\
145.6\end{array}$ \\
\hline
\end{tabular}

- See footnote a of table 3.

b $S^{\circ}$ is the entropy (exclusive of nuclear spin) of the given hydrocarbon in the thermodynamic standard gaseous state of unit fugacity (1 atm). 
$\mathrm{T}_{\mathrm{ABLE}}$ 6.-Values a of the heat content $\left(\mathrm{H}^{\circ}-\mathrm{H}_{0}{ }^{\circ}\right)$ for the seven acetylene hydrocarbons, $\mathrm{C}_{2}$ to $\mathrm{C}_{5}$, for the ideal gaseous state, to $1,500^{\circ} \mathrm{K}$

\begin{tabular}{|c|c|c|c|c|c|c|c|c|c|c|c|c|c|c|c|c|}
\hline \multirow{3}{*}{ Compound (gas) } & \multirow{3}{*}{$\begin{array}{l}\text { For- } \\
\text { mula }\end{array}$} & \multicolumn{15}{|c|}{ Temperature in ${ }^{\circ} \mathrm{K}$} \\
\hline & & 0 & 298.16 & 300 & 400 & 500 & 600 & 700 & 800 & 900 & 1,000 & 1,100 & 1,200 & 1,300 & 1,400 & 1,500 \\
\hline & & \multicolumn{15}{|c|}{ Heat content, $\mathrm{b}\left(H^{\circ}-H_{0}^{\circ}\right)$ in cal $/$ mole } \\
\hline Ethyne (acetylene) ...... & $\mathrm{C}_{2} \mathrm{H}_{2}$ & 0 & 2391.5 & 2410.8 & 3541.2 & 4791.0 & 6127 & 7533 & 8999 & 10520 & 12090 & 13706 & 15362 & 17055 & 18782 & 205 \\
\hline Propyne (methylacetylene).... & $\mathrm{C}_{3} \mathrm{H}_{4}$ & 0 & 3104 & 3131 & 4728 & 6584 & 8663 & 10935 & 13372 & 15956 & 18670 & 21490 & 24420 & 27430 & 30520 & 33670 \\
\hline $\begin{array}{l}\text { 1-Butyne (ethylacetylene) } \\
\text { 2-Butyne (dimethylacetylene) }\end{array}$ & $\begin{array}{l}\mathrm{C}_{4} \mathrm{H}_{6} \\
\mathrm{C}_{4} \mathrm{H}_{6}\end{array}$ & $\begin{array}{l}0 \\
0\end{array}$ & $\begin{array}{l}3820 \\
3961\end{array}$ & $\begin{array}{l}3850 \\
3995\end{array}$ & $\begin{array}{l}6031 \\
6060\end{array}$ & $\begin{array}{l}8610 \\
8513\end{array}$ & $\begin{array}{l}11540 \\
11320\end{array}$ & $\begin{array}{l}14760 \\
14440\end{array}$ & $\begin{array}{l}18240 \\
17830\end{array}$ & $\begin{array}{l}21940 \\
21450\end{array}$ & $\begin{array}{l}25830 \\
25290\end{array}$ & $\begin{array}{l}29890 \\
29300\end{array}$ & $\begin{array}{l}34110 \\
33480\end{array}$ & $\begin{array}{l}38450 \\
37780\end{array}$ & $\begin{array}{l}42910 \\
42210\end{array}$ & $\begin{array}{l}47460 \\
46740\end{array}$ \\
\hline 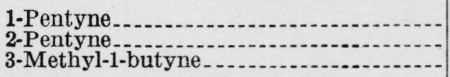 & $\begin{array}{l}\mathrm{C}_{5} \mathrm{H}_{8} \\
\mathrm{C}_{5} \mathrm{H}_{8} \\
\mathrm{C}_{5} \mathrm{H}_{8}\end{array}$ & $\begin{array}{l}0 \\
0 \\
0\end{array}$ & $\begin{array}{l}4952 \\
4675 \\
4583\end{array}$ & $\begin{array}{l}4992 \\
4716 \\
4620\end{array}$ & $\begin{array}{l}7840 \\
7360 \\
7440\end{array}$ & $\begin{array}{l}11210 \\
10540 \\
10820\end{array}$ & $\begin{array}{l}15000 \\
14200 \\
14700\end{array}$ & $\begin{array}{l}19300 \\
18300 \\
18900\end{array}$ & $\begin{array}{l}23800 \\
22700 \\
23500\end{array}$ & $\begin{array}{l}28700 \\
27400 \\
28400\end{array}$ & $\begin{array}{l}33700 \\
32500 \\
33500\end{array}$ & $\begin{array}{l}39100 \\
37700 \\
38800\end{array}$ & $\begin{array}{l}44600 \\
43200 \\
44400\end{array}$ & $\begin{array}{l}50300 \\
48800 \\
50100\end{array}$ & $\begin{array}{l}56100 \\
54600 \\
55900\end{array}$ & $\begin{array}{l}62100 \\
60500 \\
61900\end{array}$ \\
\hline
\end{tabular}

S See footnote of table

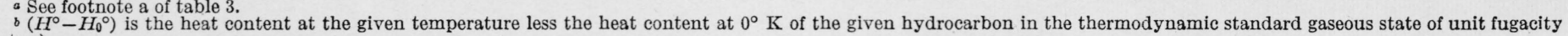
(1 atm.). 
TABLE 7.-Values of the heat capacity, $C_{p}{ }^{\circ}$, for the seven acetylene hydrocarbons, $\mathrm{C}_{2}$ to $\mathrm{C}_{5}$, for the ideal gaseous state, to $1,500^{\circ} \mathrm{K}$

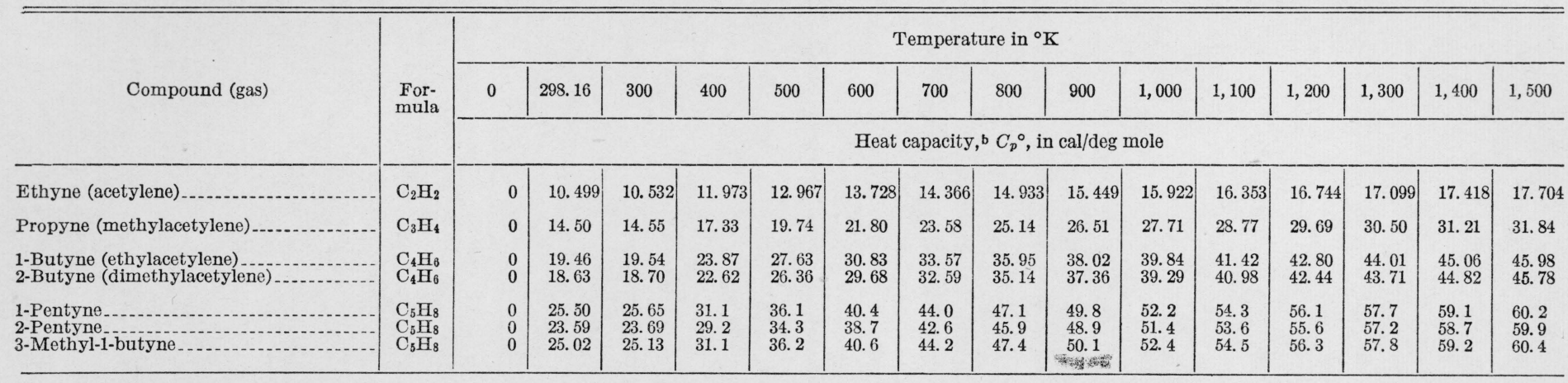

- See footnote a of table 3

b $C_{p}{ }^{\circ}$ is the heat capacity at constant pressure of the given hydrocarbon in the thermodynamic standard gaseous state of unit fugacity.(1"atm). 
TABLE 8.-Comparison of observed and calculated gas heat capacities for methylacetylene and dimethylacetylene

\begin{tabular}{|c|c|c|c|c|c|}
\hline \multicolumn{3}{|c|}{ Propyne (methylacetylene) } & \multicolumn{3}{|c|}{ 2-Butyne (dimethylacetylene) } \\
\hline$T$ & $C_{p}^{\circ}$ (obs.) & $C_{p}^{\circ}$ (calc.) & $T$ & $C_{p}^{\circ}$ (obs.) & $C_{p}^{\circ}$ (calc.) \\
\hline $\begin{array}{c}{ }^{\circ} K \\
272.28 \\
299.59 \\
332.83 \\
369.21\end{array}$ & $\begin{array}{l}\text { cal/deg mole } \\
\text { 13.76 } \\
14.58 \\
15.56 \\
16.52\end{array}$ & $\begin{array}{c}\text { cal/deg mole } \\
13.71 \\
14.54 \\
15.50 \\
16.51\end{array}$ & $\begin{array}{c}{ }^{\circ} \mathrm{K} \\
336.07 \\
369.46\end{array}$ & $\begin{array}{c}\text { cal/deg mole } \\
20.21 \\
21.43\end{array}$ & $\begin{array}{c}\text { cal/deg mole } \\
20.12 \\
21.43\end{array}$ \\
\hline
\end{tabular}

(c) A value for the entropy of dimethylacetylene in the gaseous state at $291^{\circ} \mathrm{K}$ was determined experimentally by Osborne, Garner, and Yost [14] by application of the third law of thermodynamics to calorimetric measurements down to $15^{\circ} \mathrm{K}$. Extrapolation to $291.00^{\circ}$ $\mathrm{K}$ of the values of entropy for dimethylacetylene given in table 5 yields the value $67.27 \mathrm{cal} / \mathrm{deg}$ mole, which is to be compared with the value $67.48 \pm 0.20 \mathrm{cal} / \mathrm{deg}$ mole from the experimental data of Yost and coworkers.

(d) Values of the free-energy function, entropy, and heat capacity, of gaseous methylacetylene were calculated by Crawford [9]. Crawford's values for the free-energy function at $298.16^{\circ}$ and $1,000^{\circ} \mathrm{K}$, corrected to the new values of the fundamental physical constants [1] are -48.85 and $-65.81 \mathrm{cal} / \mathrm{deg}$ mole, respectively, as compared with the values -48.89 and $-65.86 \mathrm{cal} / \mathrm{deg}$ mole, respectively, as given in table 4. See also Frank-Kamenetzky and Markovich [22].

\section{HEAT OF FORMATION, FREE ENERGY OF FORMA- TION, AND EQUILIBRIUM CONSTANT OF FORMATION}

\section{METHOD AND DATA USED IN THE CALCULATIONS}

The same method of calculation was used as described in Section IV-1 of reference [1].

For the heats of formation of the seven acetylene hydrocarbons, $\mathrm{C}_{2}$ to $\mathrm{C}_{5}$, in the gaseous state at $25^{\circ} \mathrm{C}$, according to the reaction

$$
n \mathrm{C} \text { (solid, graphite) }+(n-1) \mathrm{H}_{2} \text { (gas) }=\mathrm{C}_{n} \mathrm{H}_{2 n-2} \text { (gas), }
$$

with each reactant and product in its standard state, the following values were used [23]: Acetylene, $54.194 \pm 0.190$; propyne (methylacetylene), $44.319 \pm 0.207$; 1-butyne (ethylacetylene), $39.70 \pm 0.50$; 2-butyne (dimethylacetylene), $35.374 \pm 0.350 ; 1$-pentyne, $34.50 \pm$ 0.50 ; 2-pentyne, $30.80 \pm 0.50 ; 3$-methyl-1-butyne, $32.60 \pm 0.50 \mathrm{kcal} /$ mole.

\section{RESULTS FOR THE SEVEN ACETYLENE HYDROCARBONS, $\mathrm{C}_{2}$ TO $_{5}$}

The resulting values of the thermodynamic properties for the formation of the seven acetylene hydrocarbons, $\mathrm{C}_{2}$ to $\mathrm{C}_{5}$, in the gaseous state, from the elements carbon (solid, graphite) and hydrogen (gaseous), are presented in tables 9,10 , and 11, which give, respectively, values of the heat of formation, $\Delta H f^{\circ}$, the free energy of formation, $\Delta F f^{\circ}$, and the logarithm of the equilibrium constant of formation, $\log _{10} K f$, all to $1,500^{\circ} \mathrm{K}$. 
$\mathrm{T}_{\mathrm{ABLE}}$ 9.-Values a of the heat of formation, $\triangle H f^{\circ}$, for the seven acetylene hydrocarbons, $\mathrm{C}_{2}$ to $\mathrm{C}_{5}$, for the ideal gaseous state, to $1,500^{\circ} \mathrm{K}$

\begin{tabular}{|c|c|c|c|c|c|c|c|c|c|c|c|c|c|c|c|c|}
\hline Ethyne (acetylene) .... & $\mathrm{C}_{2} \mathrm{H}_{2}$ & 54. 329 & 54. 194 & 54. 193 & 54. 134 & 54.049 & 53.931 & 53. 787 & 53.627 & 53. 462 & 53.304 & 53. 151 & 53. 003 & 52.851 & 52.698 & 52. 548 \\
\hline Propyne (methylacetylene)...-. & $\mathrm{C}_{4} \mathrm{H}_{4}$ & 46.017 & 44. 319 & 44. 309 & 43.775 & 43. 280 & 42.829 & 42. 423 & 42.069 & 41.769 & 41.53 & 41.34 & 41.19 & 41.06 & 40.95 & 40.86 \\
\hline $\begin{array}{l}\text { 1-Butyne (ethylacetylene) } \\
\text { 2-Butyne (Dimethylacetylene) }\end{array}$ & $\begin{array}{l}\mathrm{C}_{4} \mathrm{H}_{6} \\
\mathrm{C}_{4} \mathrm{H}_{6}\end{array}$ & $\begin{array}{l}42.96 \\
38.491\end{array}$ & $\begin{array}{l}39.70 \\
35.374\end{array}$ & $\begin{array}{l}39.68 \\
35.355\end{array}$ & $\begin{array}{l}\text { 38. } 79 \\
34.348\end{array}$ & $\begin{array}{l}\text { 38. } 00 \\
33.432\end{array}$ & $\begin{array}{l}37.32 \\
32.63\end{array}$ & $\begin{array}{l}36.74 \\
31.95\end{array}$ & $\begin{array}{l}\text { 36. } 26 \\
31.38\end{array}$ & $\begin{array}{l}35.88 \\
30.92\end{array}$ & $\begin{array}{l}35.60 \\
30.59\end{array}$ & $\begin{array}{l}35.39 \\
30.33\end{array}$ & $\begin{array}{l}35.27 \\
30.17\end{array}$ & $\begin{array}{l}35.17 \\
30.03\end{array}$ & $\begin{array}{l}35.12 \\
29.95\end{array}$ & $\begin{array}{l}35.08 \\
29.89\end{array}$ \\
\hline
\end{tabular}

: See footnote (a) of table 3 .

D $\triangle H f^{\circ}$ represents the increment in heat content for the reaction of forming the given compound in the gaseous state from the elements carbon (solid, graphite) and hydroge gaseous), with all the reactants and products in their appropriate standard reference states at the temperature indicated. 
$\mathrm{T}_{\mathrm{ABLE}}$ 10.-Values a of the free energy of formation, $\Delta F f^{\circ}$, for the seven acetylene hydrocarbons, $\mathrm{C}_{2}$ to $\mathrm{C}_{5}$, for the ideal gaseous state, to $1,500^{\circ} \mathrm{K}$

\begin{tabular}{|c|c|c|c|c|c|c|c|c|c|c|c|c|c|c|c|c|}
\hline \multirow{3}{*}{ Compound (gas) } & \multirow{3}{*}{$\begin{array}{l}\text { For- } \\
\text { mula }\end{array}$} & \multicolumn{15}{|c|}{ Temperature in ${ }^{\circ} \mathrm{K}$} \\
\hline & & 0 & 298.16 & 300 & 400 & 500 & 600 & 700 & 800 & 900 & 1,000 & 1,100 & 1,200 & 1,300 & 1,400 & 1,500 \\
\hline & & \multicolumn{15}{|c|}{ Free energy of formation, b $\Delta F f^{\circ}$, in $\mathrm{kcal} / \mathrm{mole}$} \\
\hline Ethyne (acetylene) & $\mathrm{C}_{2} \mathrm{H}_{2}$ & 54.329 & 50.000 & 49.975 & 48. 577 & 47.196 & 45.835 & 44.498 & 43.178 & 41.882 & 40.604 & 39.339 & 38.089 & 36.854 & 35.624 & 34.410 \\
\hline Propyne (methylacetylene).. & $\mathrm{C}_{3} \mathrm{H}_{4}$ & 46. 017 & 46. 313 & 46.481 & 47. 287 & 48. 224 & 49.255 & 50.360 & 51.514 & 52.715 & 53.95 & 55.20 & 56.46 & 57.74 & 59.02 & 60.32 \\
\hline 1-Butyne (ethylacetylene) & $\mathrm{C}_{4} \mathrm{H}_{6}$ & 42.96 & 48.52 & 48.57 & 51.67 & 54.99 & 58.45 & 62.02 & 65.66 & 69.36 & 73.10 & 76.85 & 80.62 & 84.41 & 88.20 & 91.99 \\
\hline 2-Butyne (dimethylacetylene). & $\mathrm{C}_{4} \mathrm{H}_{6}$ & 38.491 & 44.725 & 44.783 & 48.080 & 51.620 & 55.34 & 59.18 & 63.10 & 67.10 & 71.14 & 75.20 & 79. 29 & 83.39 & 87.49 & 91.60 \\
\hline $\begin{array}{l}\text { 1-Pentyne } \\
\text { 2-Pentyne-- } \\
\text { 3-Methyl-1-butyne }\end{array}$ & $\begin{array}{l}\mathrm{C}_{6} \mathrm{H}_{8} \\
\mathrm{C}_{5} \mathrm{H}_{8} \\
\mathrm{C}_{5} \mathrm{H}_{8}\end{array}$ & $\begin{array}{l}38.90 \\
35.48 \\
37.37\end{array}$ & $\begin{array}{l}50.17 \\
46.41 \\
49.12\end{array}$ & $\begin{array}{l}50.26 \\
46.51 \\
49.23\end{array}$ & $\begin{array}{l}55.71 \\
51.96 \\
54.96\end{array}$ & $\begin{array}{l}61.42 \\
57.74 \\
60.97\end{array}$ & $\begin{array}{l}67.33 \\
63.75 \\
67.17\end{array}$ & $\begin{array}{l}73.38 \\
69.92 \\
73.50\end{array}$ & $\begin{array}{l}79.50 \\
76.19 \\
79.92\end{array}$ & $\begin{array}{l}85.69 \\
82.55 \\
86.40\end{array}$ & $\begin{array}{l}91.92 \\
88.96 \\
92.93\end{array}$ & $\begin{array}{l}98.17 \\
95.39 \\
99.47\end{array}$ & $\begin{array}{l}104.46 \\
101.84 \\
106.04\end{array}$ & $\begin{array}{l}110.78 \\
108.32 \\
112.61\end{array}$ & $\begin{array}{l}117.06 \\
114.79 \\
119.15\end{array}$ & $\begin{array}{l}123.31 \\
121.26 \\
125.68\end{array}$ \\
\hline
\end{tabular}

s. See footnote a of table 3 .

b $\Delta F f^{\circ}$ represents the increment in free energy for the reaction of forming the given compound in the gaseous state from the elements carbon (solid, graphite) and hydrogen (gaseous), with all the reactants and products in their appropriate standard reference states at the temperature indicated. 
$\mathrm{T}_{\mathrm{ABLE}}$ 11.-Values ${ }^{\text {a }}$ of the logarithm of the equilibrium constant of formation, $\log _{10} \mathrm{Kf}$, for the seven acetylene hydrocarbons, $\mathrm{C}_{2}$ to $\mathrm{C}_{5}$, for the ideal gaseous state, to $1,500^{\circ} \mathrm{K}$

\begin{tabular}{|c|c|c|c|c|c|c|c|c|c|c|c|c|c|c|c|c|}
\hline \multirow{3}{*}{ Compound } & \multirow{3}{*}{$\begin{array}{l}\text { For- } \\
\text { mula }\end{array}$} & \multicolumn{15}{|c|}{ Temperature in ${ }^{\circ} \mathrm{K}$} \\
\hline & & 0 & 298.16 & 300 & 400 & 500 & 600 & 700 & 800 & 900 & 1,000 & 1,100 & 1,200 & 1,300 & 1,400 & 1,500 \\
\hline & & \multicolumn{15}{|c|}{ Logarithm of equilibrium constant of formation, ${ }^{b} \log _{10} K f$} \\
\hline Ethyne (acetylene) & $\mathrm{C}_{2} \mathrm{H}_{2--}$ & Infinite.. & -36.6490 & -36.4058 & -26.5406 & -20.6290 & -16.6952 & -13.8925 & -11.7978 & -10.1702 & -8.8738 & -7.8158 & \begin{tabular}{l|l}
3 & -6.9369
\end{tabular} & -6.1956 & -5.5611 & -5.0134 \\
\hline $\begin{array}{l}\text { Propyne (methylacety- } \\
\text { lene). }\end{array}$ & $\mathrm{C}_{3} \mathrm{H}_{4--}$ & -...do & -33.9469 & -33.8610 & -25.8360 & -21.0781 & -17.9409 & -15.7228 & -14.0728 & -12.8007 & -11.7897 & -10.9660 & -10.2830 & -9.7072 & -9.2137 & -8.7879 \\
\hline $\begin{array}{l}\text { 1-Butyne (ethylacetylene)- } \\
\text { 2-Butyne (dimethylacety- } \\
\text { lene). }\end{array}$ & $\begin{array}{l}\mathrm{C}_{4} \mathrm{H}_{6--} \\
\mathrm{C}_{4} \mathrm{H}_{6--}\end{array}$ & (-..do-... & $\mid \begin{array}{l}-35.5616 \\
-32.7823\end{array}$ & $\begin{array}{l}-35.3839 \\
-32.6236\end{array}$ & $\begin{array}{l}-28.2320 \\
-26.2690\end{array}$ & $\begin{array}{l}-24.0341 \\
-22.5629\end{array}$ & $\begin{array}{l}-21.2892 \\
-20.1556\end{array}$ & $\begin{array}{l}-19.3627 \\
-18.4752\end{array}$ & $\begin{array}{l}-17.9369 \\
-17.2380\end{array}$ & $\begin{array}{l}-16.8427 \\
-16.2932\end{array}$ & $\mid \begin{array}{l}-15.9748 \\
-15.5471\end{array}$ & $\begin{array}{l}-15.2680 \\
-14.9409\end{array}$ & $\begin{array}{l}-14.6832 \\
-14.4400\end{array}$ & $\begin{array}{r}-14.1910 \\
-14.0186\end{array}$ & $\begin{array}{l}-13.7682 \\
-13.6574\end{array}$ & $\begin{array}{l}-13.4030 \\
-13.3462\end{array}$ \\
\hline $\begin{array}{l}\text { 1-Pentyne } \\
\text { 2-Pentyne- } \\
\text { 3-Methyl-1-butyne. }\end{array}$ & \begin{tabular}{|l|}
$\mathrm{C}_{5} \mathrm{H}_{8--}$ \\
$\mathrm{C}_{5} \mathrm{H}_{8--}$ \\
$\mathrm{C}_{5} \mathrm{H}_{8--}$
\end{tabular} & 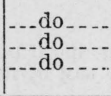 & $\begin{array}{l}-36.7712 \\
-34.0177 \\
-36.0061 \\
-\end{array}$ & $\begin{array}{l}-36.6154 \\
-33.8792 \\
-35.8614\end{array}$ & $\begin{array}{l}-30.4369 \\
-28.3891 \\
-30.0293\end{array}$ & $\begin{array}{l}-26.8440 \\
-25.2377 \\
-26.6495\end{array}$ & $\mid \begin{array}{l}-24.5230 \\
-23.2205 \\
-24.4662\end{array}$ & $\begin{array}{l}-22.9082 \\
-21.8297 \\
-22.9486\end{array}$ & $\mid \begin{array}{l}-21.7167 \\
-20.8130 \\
-21.8318\end{array}$ & $\left|\begin{array}{l}-20.8084 \\
-20.0457 \\
-20.9810\end{array}\right|$ & $\mid \begin{array}{l}-20.0881 \\
-19.4412 \\
-20.3088\end{array}$ & $\begin{array}{l}-19.5046 \\
-18.9519 \\
-19.7622\end{array}$ & $\begin{array}{l}-19.0244 \\
-18.5480 \\
-19.3118\end{array}$ & $\begin{array}{l}-18.6227 \\
-18.2095 \\
-18.9315\end{array}$ & $\begin{array}{l}-18.2733 \\
-17.9186 \\
-18.6004\end{array}$ & $\begin{array}{l}-17.9662 \\
-17.6668 \\
-18.3115\end{array}$ \\
\hline
\end{tabular}

- See footnote (a) of table 3 .

be (solid, graphite) and hydrogen (gaseous), with all the reactants and products in their appropriate standard reference states at the temperature indicated. 
Figure 1 shows the thermodynamic stability of the four 1-alkynes in the gaseous state as a function of temperature, in the form of a plot of the standard free energy of formation, per carbon atom, divided by the absolute temperature. This plot may be compared with corresponding plots for the normal paraffins and the 1-alkenes, which are given in other reports from this laboratory $[24,25]$.

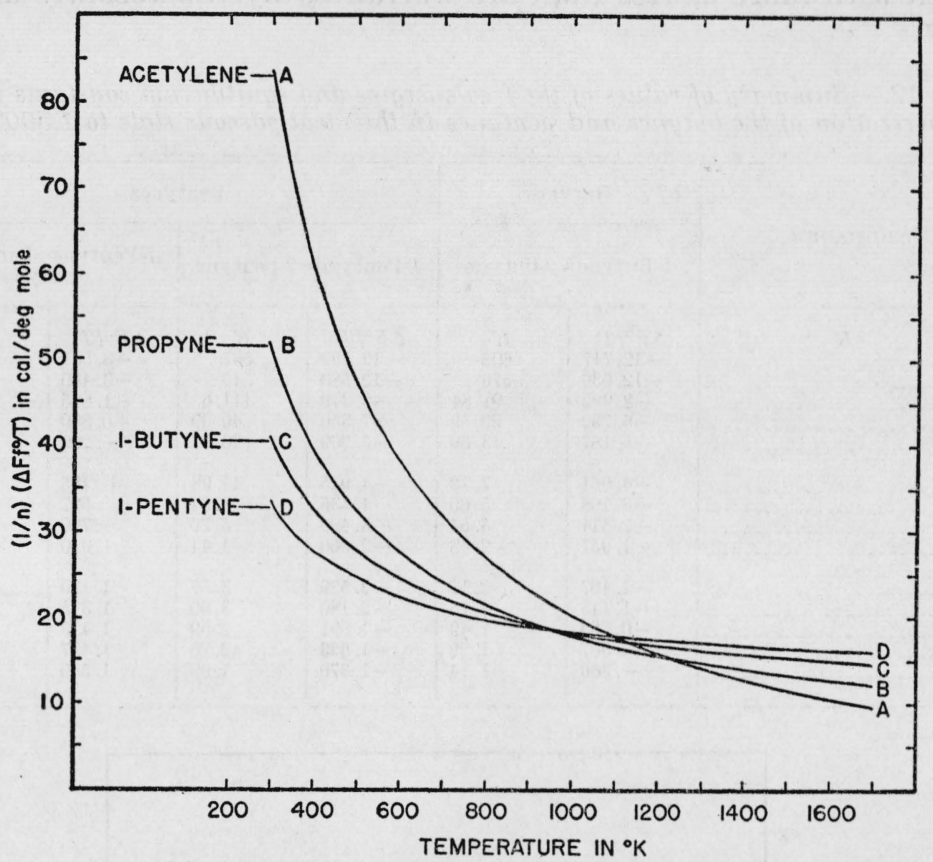

FIGURE 1.-Thermodynamic stability of the 1-alkyne hydrocarbons in the gaseous state as a function of temperature.

The scale of ordinates gives the value of $(\mathrm{l} / n)\left(\Delta F f^{\circ} / T\right)$ in calories per degree mole, where $n$ is the number of carbon atoms per molecule, $T$ is the absolute temperature in degrees Kelvin, and $\Delta F f^{\circ}$ is the standard free energy of formation of the hydrocarbon from the elements, solid carbon (graphite) and gaseous hydrogen, as given in table 10 . The scale of abscissas gives the temperature in degrees Kelvin. Points below the zero line indicate that the gaseous hydrocarbon in its standard state has a thermodynamic tendency to be formed from solid carbon (graphite) and gaseous hydrogen in their respective standard states.

\section{FREE ENERGIES AND EQUILIBRIUM CONSTANTS OF ISOMERIZATION OF THE BUTYNES AND THE PENTYNES}

From the values in tables 10 and 11, calculations were made of the values of the free energies, equilibrium constants, and equilibrium concentrations for the isomerization of the butynes and pentynes, according to the reaction.

$$
\mathrm{C}_{n} \mathrm{H}_{2 n-2} \text { (1-alkyne, gas) }=\mathrm{C}_{n} \mathrm{H}_{2 n-2} \text { (isomeric alkyne, gas). }
$$

In table 12 are given the following:

$\Delta F^{\circ} / T$, the standard free-energy change divided by the absolute temperature, for the isomerization reaction as written; $K$, the equilibrium constant, for the isomerization reaction as written. In table 13 are given values of $N$, the mole fraction of the given isomer present

$$
673829-46-4
$$


at equilibrium with its other isomers (acetylene compounds). For any two isomers, the ratio of the corresponding values of $K$ in table 12 (or of $N$ in table 13 ) gives the ratio of the amounts of those two isomers present at equilibrium with one another in the gas phase at the given temperature. For the purpose of retaining the significance of their change with temperature, the values in tables 12 and 13 are written with more figures than are warranted by the absolute uncertainty.

TABLE 12.-Summary of values of the free-energies and equilibrium constants for the isomerization of the butynes and pentynes in the ideal gaseous state to $1,500^{\circ} \mathrm{K}$

\begin{tabular}{|c|c|c|c|c|c|c|}
\hline \multirow{2}{*}{ Temperature } & \multicolumn{2}{|c|}{ Butynes } & \multicolumn{4}{|c|}{ Pentynes } \\
\hline & \multicolumn{2}{|c|}{ 1-Butyne=2-butyne } & \multicolumn{2}{|c|}{ 1-Pentyne = 2-pentyne } & \multicolumn{2}{|c|}{$\begin{array}{c}\text { 1-Pentyne }=3 \text {-methyl- } \\
\text { 1-butyne }\end{array}$} \\
\hline $\begin{array}{l}298.16 \\
300 \\
400 \\
500 \\
600\end{array}$ & $\begin{array}{l}\Delta F^{\circ} / T \\
-12.717 \\
-12.630 \\
-8.982 \\
-6.732 \\
-5.187\end{array}$ & $\begin{array}{l}K \\
602 \\
576 \\
91.84 \\
29.59 \\
13.60\end{array}$ & $\begin{array}{l}\Delta F^{\circ} / T \\
-12.599 \\
-12.580 \\
-9.370 \\
-7.350 \\
-5.960\end{array}$ & $\begin{array}{l}K \\
567 \\
545 \\
111.6 \\
40.39 \\
20.07\end{array}$ & $\begin{array}{r}\Delta F^{\circ} / T \\
-3.501 \\
-3.450 \\
-1.865 \\
-0.890 \\
-.260\end{array}$ & $\begin{array}{r}\boldsymbol{K} \\
\mathbf{5 . 8 2} \\
5.68 \\
2.56 \\
1.56 \\
1.14\end{array}$ \\
\hline $\begin{array}{l}700 \\
800 \\
900 \\
1,000\end{array}$ & $\begin{array}{l}-4.061 \\
-3.198 \\
-2.514 \\
-1.957\end{array}$ & $\begin{array}{l}7.72 \\
5.00 \\
3.54 \\
2.68\end{array}$ & $\begin{array}{l}-4.935 \\
-4.135 \\
-3.490 \\
-2.960\end{array}$ & $\begin{array}{r}11.98 \\
8.01 \\
5.79 \\
4.44\end{array}$ & $\begin{array}{r}+.185 \\
. .527 \\
.790 \\
1.010\end{array}$ & $\begin{array}{l}0.91 \\
.77 \\
.67 \\
.60\end{array}$ \\
\hline $\begin{array}{l}1,100 \\
1,200 \\
1,300 \\
1,400 \\
1,500\end{array}$ & $\begin{array}{r}-1.497 \\
-1.113 \\
-0.789 \\
-.507 \\
-.360\end{array}$ & $\begin{array}{l}2.12 \\
1.75 \\
1.49 \\
1.29 \\
1.14\end{array}$ & $\begin{array}{l}-2.529 \\
-2.180 \\
-1.891 \\
-1.623 \\
-1.370\end{array}$ & $\begin{array}{l}3.57 \\
3.00 \\
2.59 \\
2.26 \\
1.99\end{array}$ & $\begin{array}{l}1.179 \\
1.315 \\
1.413 \\
1.497 \\
1.580\end{array}$ & $\begin{array}{l}.55 \\
.52 \\
.49 \\
.47 \\
.45\end{array}$ \\
\hline
\end{tabular}

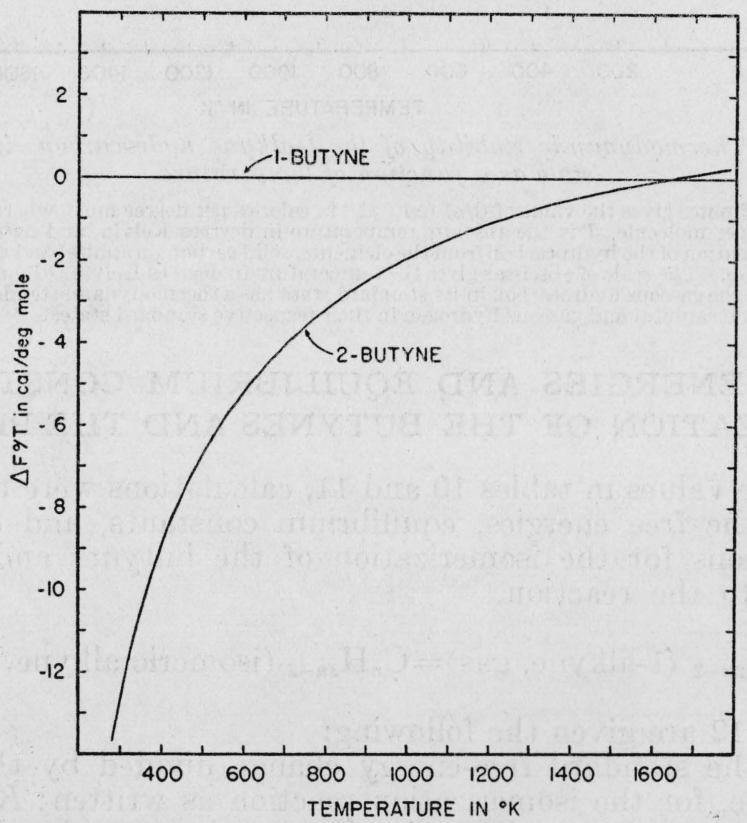

FIGURE 2.-Free energy of isomerization of the butynes.

The scale of ordinates gives the value of $\Delta F^{\circ} / T$, in calories per degree mole, for the isomerization of 1. butyne (gas) into 2-butyne (gas). The scale of abscissas gives the temperature in degrees Kelvin. 
TABLE 13.-Values of the equilibrium concentrations for the isomerization of the butynes and pentynes in the ideal gaseous state to $1,500^{\circ} \mathrm{K}$

\begin{tabular}{|c|c|c|c|c|c|}
\hline \multirow{3}{*}{ Temperature } & \multicolumn{5}{|c|}{ Composition, in mole fraction, of equilibrium mixtures of isomers } \\
\hline & \multicolumn{2}{|c|}{ Butynes } & \multicolumn{3}{|c|}{ Pentynes } \\
\hline & 1-Butyne & 2-Butyne & 1-Pentyne & 2-Pentyne & $\begin{array}{l}\text { 3-Methyl-1- } \\
\text { butyne }\end{array}$ \\
\hline $\begin{array}{c}{ }^{\circ} K \\
608.16 \\
400 \\
600\end{array}$ & $\begin{array}{r}0.002 \\
.002 \\
.011 \\
.033 \\
.068\end{array}$ & $\begin{array}{r}0.998 \\
.998 \\
.989 \\
.967 \\
.932\end{array}$ & $\begin{array}{r}0.002 \\
.002 \\
.009 \\
.023 \\
.045\end{array}$ & $\begin{array}{r}0.988 \\
.988 \\
.969 \\
.941 \\
.903\end{array}$ & $\begin{array}{r}0.010 \\
.010 \\
.022 \\
.036 \\
.052\end{array}$ \\
\hline 9000000 & $\begin{array}{l}.115 \\
.167 \\
.220 \\
.272\end{array}$ & $\begin{array}{l}.885 \\
.833 \\
.780 \\
.728\end{array}$ & $\begin{array}{l}.072 \\
.102 \\
.134 \\
.166\end{array}$ & $\begin{array}{l}.863 \\
.820 \\
.776 \\
.734\end{array}$ & $\begin{array}{l}.065 \\
.078 \\
.090 \\
.100\end{array}$ \\
\hline $\begin{array}{l}1,100 \\
1,200 \\
1,300 \\
1,400\end{array}$ & $\begin{array}{l}.320 \\
.364 \\
.402 \\
.436 \\
.467\end{array}$ & $\begin{array}{l}.680 \\
.636 \\
.598 \\
.564 \\
.533\end{array}$ & $\begin{array}{l}195 \\
.222 \\
.245 \\
.268 \\
.290\end{array}$ & $\begin{array}{l}.697 \\
.664 \\
.635 \\
.606 \\
.579\end{array}$ & $\begin{array}{l}.108 \\
.114 \\
.120 \\
.126 \\
.131\end{array}$ \\
\hline
\end{tabular}

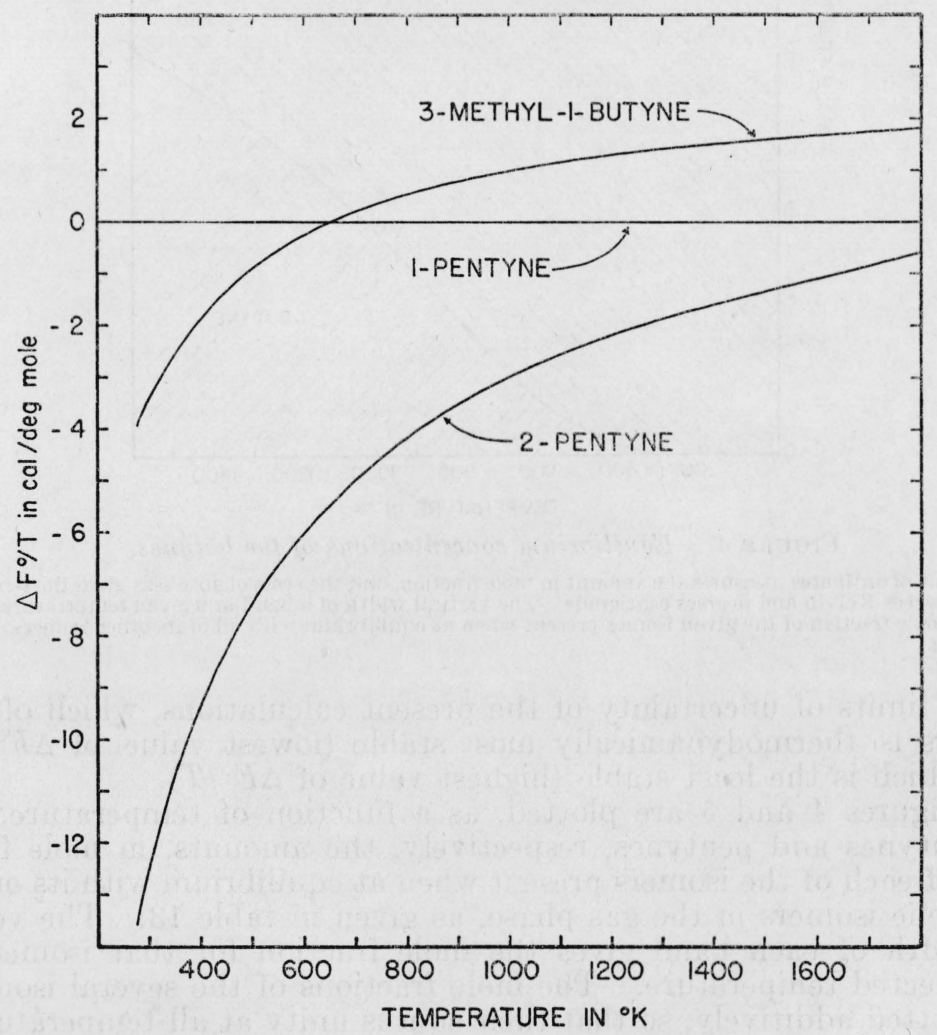

Figure 3.-Free energy of isomerization of the pentynes.

The scale of ordinates gives the value of $\Delta F^{\circ} / T$, in calories per degree mole, for the isomerization of 1 pentyne (gas) into the appropriate isomeric pentyne (gas). The scale of abscisssas gives the temperature in degrees Kelvin. 
In figures 2 and 3 are plotted, as a function of the temperature, the values of $\Delta F^{\circ} / T$ given in table 12 for the isomerization of the butynes and the pentynes, respectively. These plots may be compared with corresponding plots for the butanes, pentanes, hexanes, heptanes, and octanes, which have already been published [26, 27 , and for the butenes, pentenes, and hexenes, which will appear in another report from this laboratory [25]. From these charts one may see at a glance, for any temperature in the given range and with-

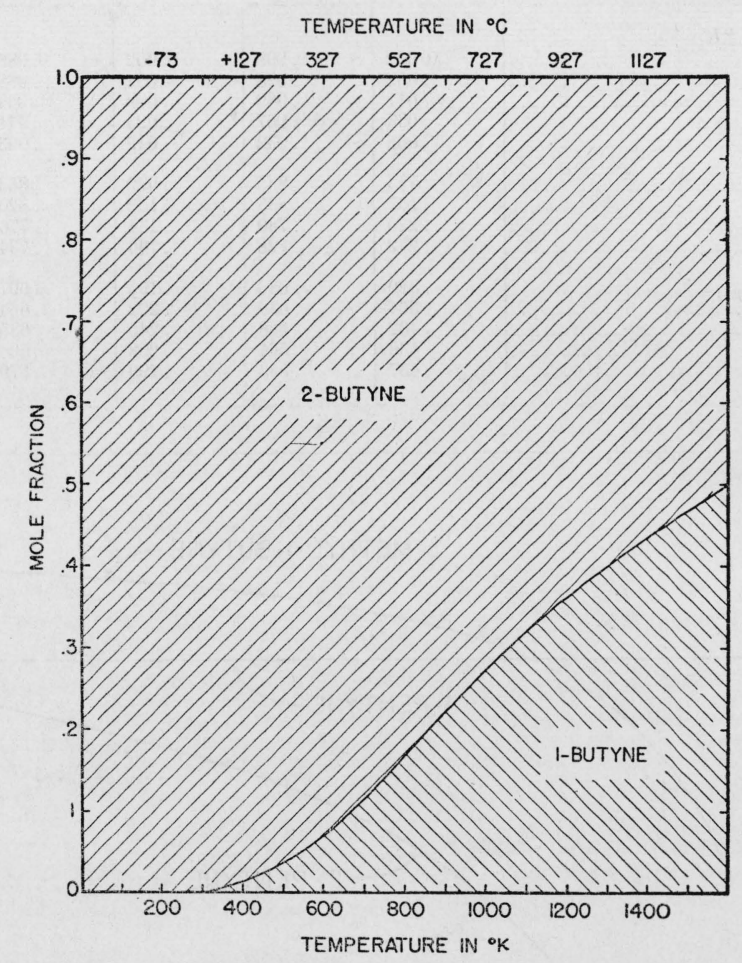

FIgURE 4.-Equilibrium concentrations of the butynes.

The scale of ordinates measures the amount in mole fraction, and the scale of abscissas gives the temperature in degrees Kelvin and degrees centigrade. The vertical width of a band at a given temperature measures the mole fraction of the given isomer present when at equilibrium with all of its other isomers, in the gas phase.

in the limits of uncertainty of the present calculations, which of the isomers is thermodynamically most stable (lowest value of $\Delta F^{\circ} / T$ ) and which is the least stable (highest value of $\Delta F^{\circ} / T$ ).

In figures 4 and 5 are plotted, as a function of temperature, for the butynes and pentynes, respectively, the amounts, in mole fraction, of each of the isomers present when at equilibrium with its other acetylene isomers in the gas phase, as given in table 13 . The vertical width of each band gives the mole fraction for that isomer at the selected temperature. The mole fractions of the several isomers are plotted additively, so that their sum is unity at all temperatures. 


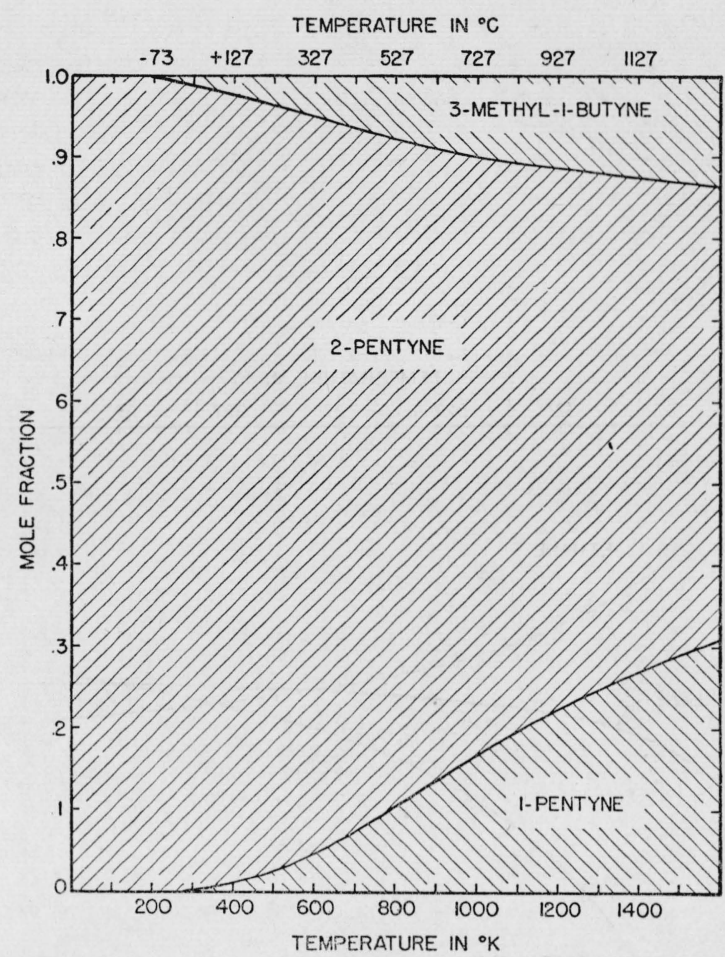

FigURe 5.-Equilibrium concentrations of the pentynes.

The scale of ordinates measures the amount in mole fraction, and the scale of abscissas gives the tempera. ture in degrees Kelvin and degrees centigrade. The vertical width of a band at a given temperature measures the mole fraction of the given isomer present when at equilibrium with all of its other isomers, in the gas phase.

\section{FREE ENERGIES AND EQUILIBRIUM CONSTANTS OF DEHYDROGENATION, TO THE CORRESPONDING ACET- YLENES, OF THE $C_{2}$ TO $C_{5}$ NORMAL PARAFFINS AND 1-ALKENES}

In figures $6,7,8$, and 9 are plotted as a function of temperature, for the $\mathrm{C}_{2}, \mathrm{C}_{3}, \mathrm{C}_{4}$, and $\mathrm{C}_{5}$ hydrocarbons, respectively, values of $\log _{10} K f$, the logarithm (to the base 10) of the equilibrium constant of the reaction of forming the given hydrocarbon in its standard gaseous state from the elements solid carbon (graphite) and gaseous hydrogen, according to the following equations for the paraffin, olefin, and the acetylene series, respectively:

$$
\begin{gathered}
n \mathrm{C} \text { (solid, graphite) }+\underset{\text { paraffin) }}{(n+1) \mathrm{H}_{2} \text { (gas) }=\mathrm{C}_{n} \mathrm{H}_{2 n+2} \text { (gas, normal }} \\
n \mathrm{C} \text { (solid, graphite) }+n \mathrm{H}_{2} \text { (gas) }=\mathrm{C}_{n} \mathrm{H}_{2 n} \text { (gas, 1-alkene) } \\
n \mathrm{C} \text { (solid, graphite) }+(n-1) \mathrm{H}_{2} \text { (gas) }=\mathrm{C}_{n} \mathrm{H}_{2 n-2} \text { (gas, 1-alkyne). }
\end{gathered}
$$

In these calculations, the values for the 1-alkynes are taken from this report, the values for the normal paraffins from reference [24], and those for the 1-alkenes from reference [25]. 
TEMPERATURE IN ${ }^{\circ} \mathrm{C}$

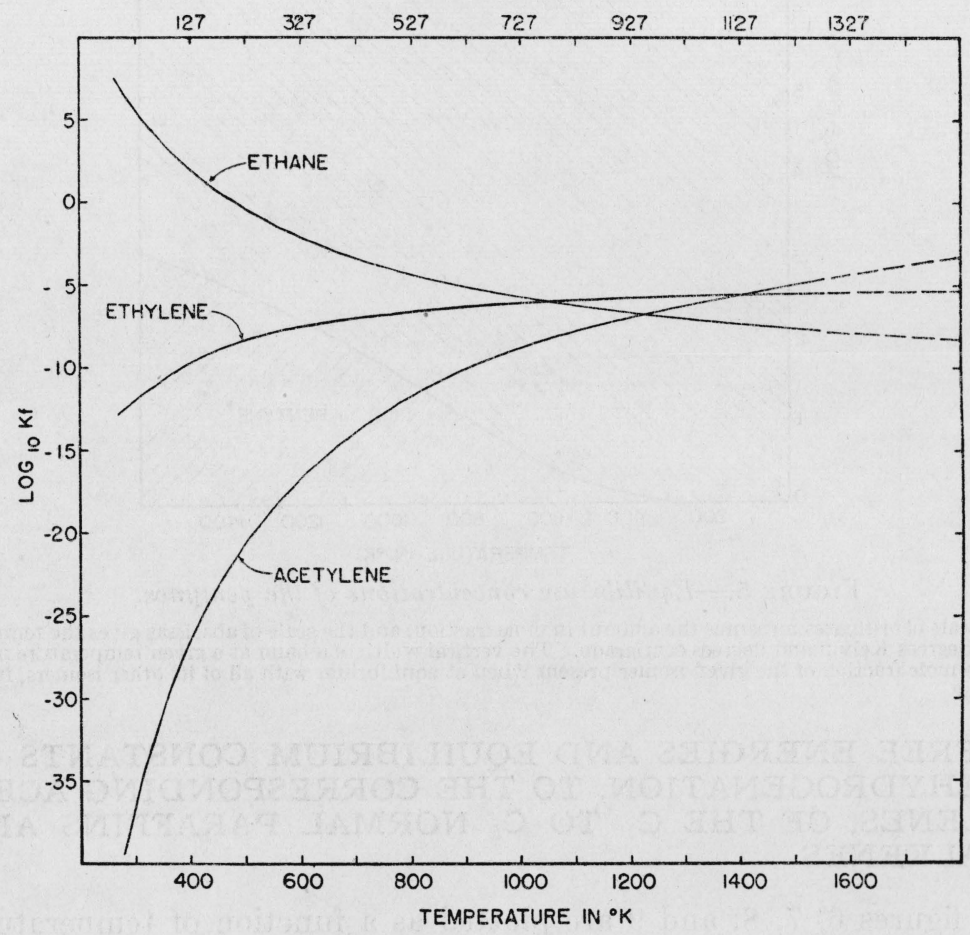

FIGURE 6.-Logarithm of the equilibrium constant of formation of ethane, ethylene, and acetylene.

The scale of ordinates gives the logarithm (to the base 10) of the equilibrium constant of formation of the hydrocarbons in the gaseous state from the elements solid carbon (graphite) and gaseous hydrogen, with each substance in its thermodynamic standard state of unit fugacity. The scale of abscissas gives the temperature in degrees Kelvin and degrees centigrade. (See text.) 
TEMPERATURE IN ${ }^{\circ} \mathrm{C}$

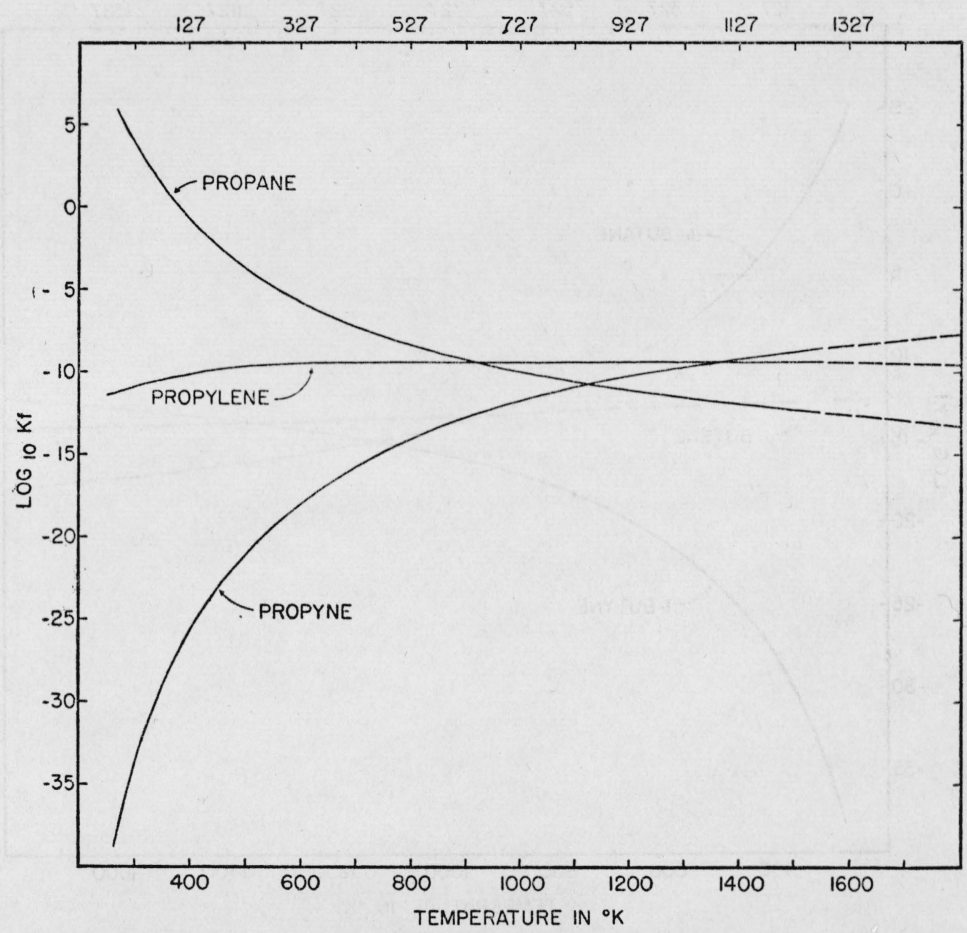

Figure 7.-Logarithm of the equilibrium constant of formation of propane, propylene, and propyne.

The scale of ordinates gives the logarithm (to the base 10) of the equilibrium constant of formation of the hydrocarbons from the elements solid carbon (graphite) and gaseous hydrogen, with each substance in its thermodynamic standard state of unit fugacity. The scale of abscissas gives the temperature in degrees Kelvin and degrees centigrade. (See text.) 
TEMPERATURE IN ${ }^{\circ} \mathrm{C}$

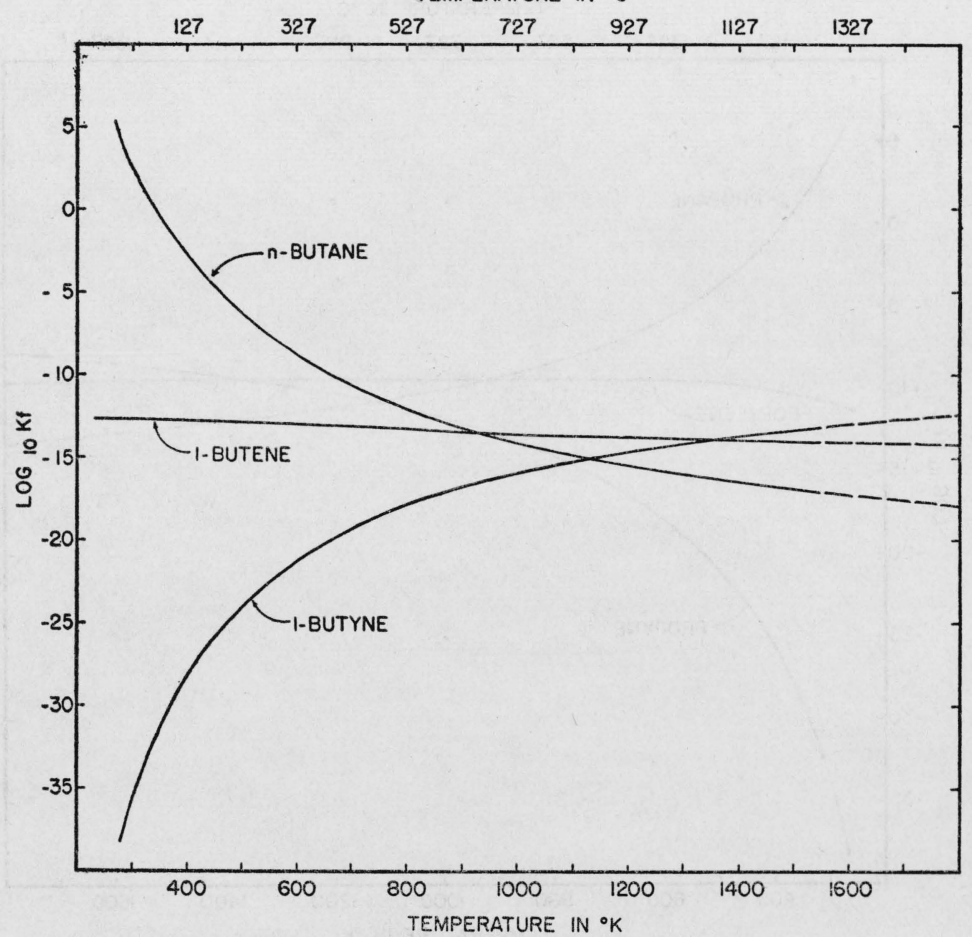

FIgURE 8.-Logarithm of the equilibrium constant of formation of n-butane, 1-butene, and 1-butyne.

The scale of ordinates gives the logarithm (to the base 10) of the equilibrium constant of formation of the hydrocarbons from the elements solid carbon (graphite) and gaseous hydrogen with each substance in its thermodynamic standard state of unit fugacity. The scale of abscissas gives the temperature in degrees Kelvin and degrees centigrade. (See text.) 
The differences in the values of the ordinates of any given pair of curves in figures $6,7,8$, and 9 give the values of the logarithm of the

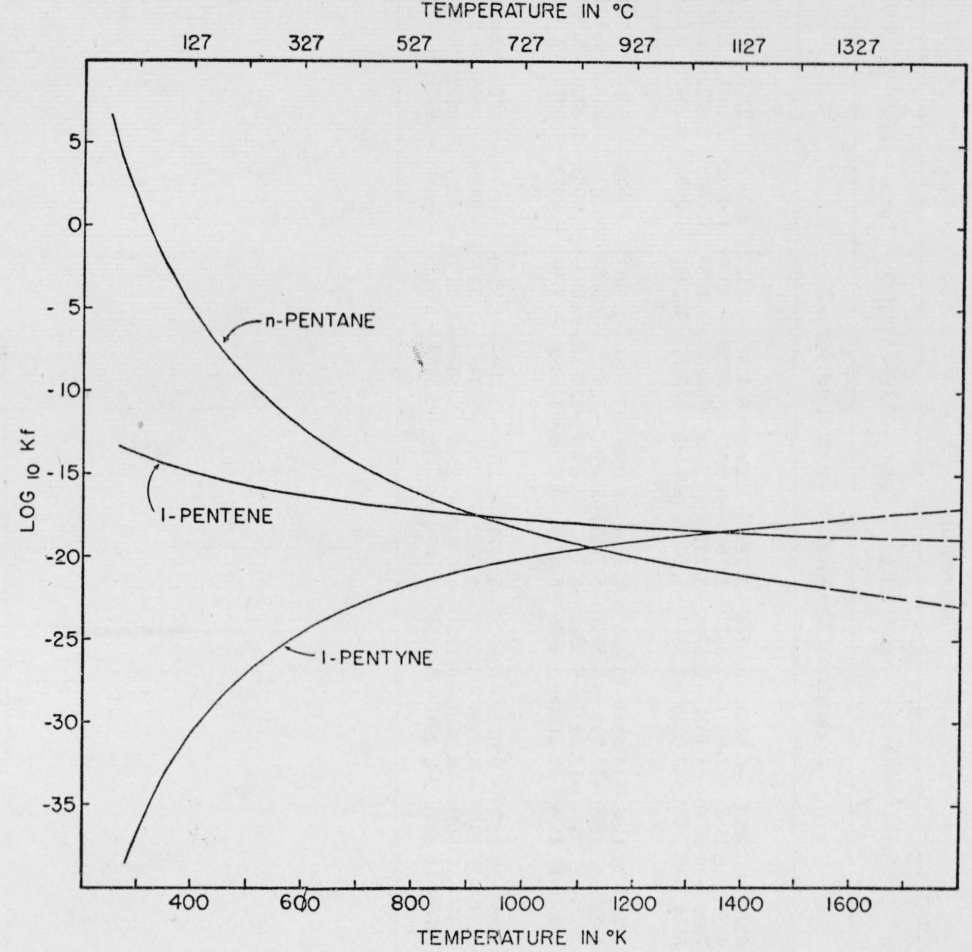

FIgURE 9.-Logarithm of the equilibrium constant of formation of $n$-pentane, 1-pentene, and 1-pentyne.

The scale of ordinates gives the logarithm (to the base 10) of the equilibrium constant of formation of the hydrocarbons from the elements solid carbon (graphite) and gaseous hydrogen, with each substance in its thermodynamic standard state of unit fugacity. The scale of abscissas gives the temperature in degrees Kelvin and degrees centigrade. (See text.)

equilibrium constant for the appropriate reaction of hydrogenation or dehydrogenation. Values of $\log K$ and $K$ for the several reactions of dehydrogenation (and hydrogenation) are given in table 14. 
$\mathrm{T}_{\mathrm{ABLE}}$ 14.-Logarithm of the equilibrium constant for the dehydrogenation reactions involving n-paraffins, 1-alkenes and 1-alkynes, $\mathrm{C}_{2}$ to $\mathrm{C}_{5}$

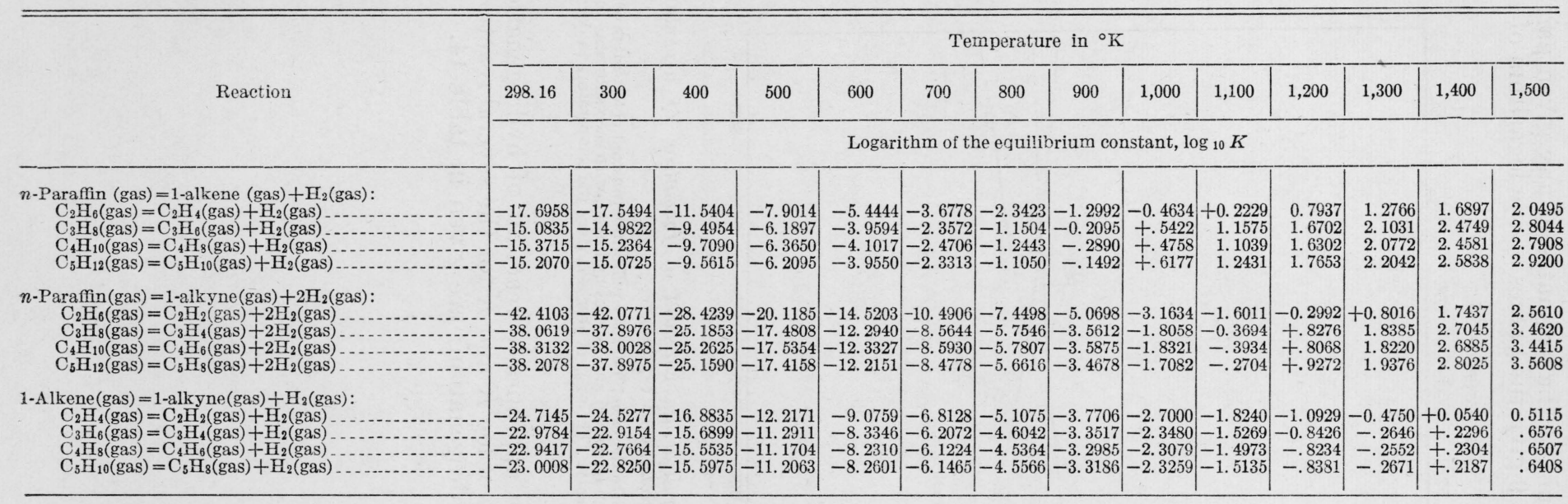


The plots in figures $6,7,8$, and 9 show, for molecules of the same number of carbon atoms, the range of temperature in which the normal paraffin, 1-alkene, and 1-alkyne hydrocarbons are relatively most stable (highest value of log $K f$ ) in the presence of hydrogen, with each substance (including the hydrogen) in its thermodynamic standard state of unit fugacity of 1 atmosphere. These ranges of temperature are given in table 15 in degrees Kelvin and centigrade, and are important in the analysis of any process involving hydrogenation or dehydrogenation of these molecules.

TABLE 15.-Ranges of temperature in which, for molecules of the same number of carbon atoms, the normal paraffin, 1-alkene, and 1-alkyne hydrocarbons, $\mathbf{C}_{2}$ to $\mathrm{C}_{5}$, are relatively most stable in the presence of hydrogen, with each substance in its thermodynamic standard state

\begin{tabular}{|c|c|c|c|c|c|c|}
\hline \multirow{3}{*}{ Number of $\mathrm{C}$ atoms } & \multicolumn{2}{|c|}{$n$-Paraffin } & \multicolumn{2}{|c|}{ 1-Alkene } & \multicolumn{2}{|c|}{ 1-Alkyne } \\
\hline & \multicolumn{6}{|c|}{ Range of temperature a } \\
\hline & \multicolumn{2}{|c|}{ Below } & \multicolumn{2}{|c|}{ Between } & \multicolumn{2}{|c|}{ Above } \\
\hline $\begin{array}{l}\mathrm{C}_{2} \ldots \\
\mathrm{C}_{3} \ldots \\
\mathrm{C}_{4} \ldots \\
\mathrm{C}_{5} \ldots \ldots\end{array}$ & $\begin{array}{r}{ }^{\circ} \mathrm{K} \\
1,065 \\
930 \\
935 \\
915\end{array}$ & $\begin{array}{l}{ }^{\circ} \mathrm{C} \\
792 \\
657 \\
662 \\
642\end{array}$ & $\begin{array}{r}{ }^{\circ} \mathrm{K} \\
1,065 \text { to } 1,390 \\
930 \text { to } 1,350 \\
935 \text { to } 1,350 \\
915 \text { to } 1,350\end{array}$ & $\begin{array}{c}{ }^{\circ} \mathrm{C} \\
792 \text { to } 1,117 \\
657 \text { to } 1,077 \\
662 \text { to } 1,077 \\
642 \text { to } 1,077\end{array}$ & $\begin{array}{l}{ }^{\circ} K \\
1,390 \\
1,350 \\
1,350 \\
1,350\end{array}$ & $\begin{array}{l}{ }^{\circ} C \\
1,117 \\
1,077 \\
1,077 \\
1,077\end{array}$ \\
\hline
\end{tabular}

- Temperatures rounded to the nearest $5^{\circ} \mathrm{K}$ :

\section{REFERENCES}

[1] D. D. Wagman, J. E. Kilpatrick, W. J. Taylor, K. S. Pitzer, and F. D. Rossini, J. Research NBS 34, 143 (1945) RP1634.

[2] J. E. Mayer and M. G. Mayer, Statistical mechanics (John Wiley \& Sons, New York, N. Y., 1940).

[3] W. H. Stockmayer, G. M. Kavanagh, and H. S. Mickley, J. Chem. Phys. 12, 408 (1944).

[4] T. Y. Wu, J. Chem. Phys. 8, 489 (1940).

[5] R. Mecke and R. Ziegler, Z. Physik 101, 405 (1936).

[6] G. Herzberg, F. Patat, and H. Verleger, J. Phys. Chem. 41, 123 (1937).

[7] R. M. Badger and S. H. Bauer, J. Chem. Phys. 5, 599 (1937).

[8] L. Pauling, H. D. Springall, and K. J. Palmer, J. Am. Chem. Soc. 61, 927 (1939).

19] B. L. Crawford, Jr., J. Chem. Phys. 8, 526 (1940).

[10] B. L. Crawford, Jr., J. Chem. Phys. ', 555 (1939).

[11] G. B. Kistiakowsky and W. W. Rice, J. Chem. Phys. 8, 618 (1940).

[12] F. F. Cleveland and M. J. Murray, J. Chem. Phys. 10, 174 (1942).

[13] K. S. Pitzer, J. Chem. Phys. 12, 310 (1944).

[14] D. W. Osborne, C. S. Garner, and D. M. Yost, J. Am. Chem. Soc. 63, 3492 (1941).

[15] K. S. Pitzer and W. D. Gwinn, J. Chem. Phys. 10, 428 (1942).

[16] American Petroleum Institute Research Project 44 at the National Bureau of Standards. Catalog of Infrared Absorption Spectrograms. Serial No. 45, Methylacetylene. Spectrogram contributed by the Shell Development Co., Emeryville, Calif.

[17] K. S. Pitzer, Ind. Eng. Chem. 36, 829 (1944).

[18] J. E. Kilpatrick and K. S. Pitzer, American Petroleum Institute Research Project 44, National Bureau of Standards. Unpublished data.

[19] A. R. Gordon, J. Chem. Phys. 6, 219 (1938).

[20] L. S. Kassel, J. Am. Chem. Soc. 55, 1351 (1933).

[21] W. J. Taylor, J. Research NBS 35, 151 (1945) RP1667.

[22] D. A. Frank-Kamenetzky and V. G. Markovich. Acta Physicochim. (U. R. S. S.) 17, 308 (1942). 
[23] E. J. Prosen and F. D. Rossini, National Bureau of Standards. Unpublished data.

[24] E. J. Prosen, K. S. Pitzer, and F. D. Rossini, J. Research NBS 34, 403 (1945) RP1650.

[25] J. E. Kilpatrick, E. J. Prosen, K. S. Pitzer, and F. D. Rossini, American Petroleum Institute Research Project 44, National Bureau of Standards. Unpublished data.

[26] F. D. Rossini, E. J. Prosen, and K. S. Pitzer, J. Research NBS 27, 529 (1941) RP1440.

[27] E. J. Prosen, K. S. Pitzer, and F. D. Rossini, J. Research NBS 34, 255 (1945) RP1641.

[28] American Petroleum Institute Research Project 44 at the National Bureau of Standards. Catalog of Infrared Absorption Spectrograms. Serial No. 13, 1-Butyne (ethylacetylene). Spectrogram contributed jointly by the Phillips Petroleum Co., Bartlesville, Oklahoma and the University of Oklahoma Research Institute, Norman, Okla.

[29] R. M. Badger, J. Chem. Phys. 2, 128 (1934); 3, 710 (1935).

[30] G. Herzberg, Infrared and Raman spectra of polyatomic molecules, page 437 (D. Van Nostrand Co., New York, N. Y., 1945).

Washington, June 1, 1945. 